\title{
Chapter 2 \\ Carbon, Water and Energy Fluxes of Terrestrial Ecosystems in Italy
}

\author{
Dario Papale, Mirco Migliavacca, Edoardo Cremonese, Alessandro Cescatti, \\ Giorgio Alberti, Manuela Balzarolo, Luca Belelli Marchesini, \\ Eleonora Canfora, Raffaele Casa, Pierpaolo Duce, Osvaldo Facini, \\ Marta Galvagno, Lorenzo Genesio, Damiano Gianelle, Vincenzo Magliulo, \\ Giorgio Matteucci, Leonardo Montagnani, Fabio Petrella, Andrea Pitacco, \\ Guenther Seufert, Donatella Spano, Paolo Stefani, Francesco P. Vaccari \\ and Riccardo Valentini
}

\begin{abstract}
In this chapter the Eddy Covariance network of Italy is presented, with a short introduction to each of the 29 sites that were active during the CarboItaly project. These sites provided a unique dataset for a better study and understanding of the carbon cycle of terrestrial ecosystems and the links between carbon sink capacity and the main environmental factors. After a number of examples of Eddy Covariance time series where it is possible to see the effect of interannual climate variability and disturbances and managements practices, an analysis of the role of
\end{abstract}

D. Papale $(\bowtie) \cdot$ M. Balzarolo $\cdot$ L. Belelli Marchesini · E. Canfora · P. Stefani · R. Valentini Department for Innovation in Biological, Agro-Food and Forest System (DIBAF),

University of Tuscia, Viterbo, Italy

e-mail: darpap@unitus.it

M. Migliavacca · A. Cescatti · G. Seufert

Joint Research Centre, Institute for Environment and Sustainability, European Commission, Ispra, Italy

E. Cremonese $\cdot$ M. Galvagno

ARPA Valle D’Aosta, Aosta, Italy

G. Alberti

Department of Agricultural and Environmental Sciences, University of Udine, Udine, Italy

R. Casa

DAFNE, University of Tuscia, Viterbo, Italy

O. Facini

IBIMET, CNR, Bologna, Italy

L. Genesio · F.P. Vaccari

IBIMET, CNR, Florence, Italy

D. Gianelle

Department of Sustainable Agro-Ecosystems and Bioresources, Research and Innovation

Centre, Fondazione Edmund Mach, Michele All’ Adige, Trento, Italy

R. Valentini and F. Miglietta (eds.), The Greenhouse Gas Balance of Italy,

Environmental Science and Engineering, DOI 10.1007/978-3-642-32424-6_2 
the Carbon Uptake Period in the total Net Ecosystem Exchange (NEE) definition and a study of the effect of temperature and precipitation on the interannual variability of NEE are presented in order to show the way these data can contribute to a better understanding of the role and response of ecosystems to climate change.

\subsection{Introduction}

Monitoring carbon, water and energy fluxes between terrestrial ecosystems and atmosphere is essential for a better understanding of the biological and ecological processes, also in relation to climate variability and climate change, and to assess the carbon balance of the different ecosystems and their ability to sequester $\mathrm{CO}_{2}$ from the atmosphere.

In order to improve the understanding of the quantities involved in the carbon balance of terrestrial ecosystems, it is important to provide the following definitions: it is defined Gross Primary Production (GPP) of an ecosystem, the total amount of $\mathrm{CO}_{2}$ that is fixed by the vegetation in photosynthesis. The synthesis of new plant tissues and the maintenance of the plants themselves require energy that is provided by the autotrophic respiration $(\mathrm{Ra})$. The difference between the amount of carbon fixed by photosynthesis and respired by the vegetation is defined Net Primary Production (NPP):

$$
\mathrm{NPP}=\mathrm{GPP}-\mathrm{Ra}
$$

V. Magliulo

ISAFOM, CNR, Ercolano, NA, Italy

G. Matteucci

ISAFOM, CNR, Rende, CS, Italy

G. Matteucci

IBAF, CNR, Monterotondo, RM, Italy

L. Montagnani

Forest Services and Agency for the Environment, Autonomous Province of Bolzano,

Faculty of Science and Technology, Free University of Bolzano, Bolzano, Italy

F. Petrella

Institute for Wood Plant and Environment (IPLA),

Environmental Disease and Soil Conservation Unit, Turin, Italy

A. Pitacco

DAFNAE, University of Padua, Padua, Italy

D. Spano

Department of Science for Nature and Environmental Resources (DIPNET),

University of Sassari, via E. de Nicola 9, 07100 Sassari, Italy

P. Duce

IBIMET, CNR, Sassari, Italy

D. Spano

Impacts on Agriculture, Forest and Natural Ecosystem Division (IAFENT),

Euro-Mediterranean Center on Climate Changes (CMCC), Sassari, Italy 
The NPP is allocated to the production of biomass (wood, leaves, roots, fruits, seeds etc.) and respired back to the atmosphere mainly due to decomposition by microbial activities. The quantity of carbon lost by respiration for heterotrophic organisms is defined heterotrophic respiration $(\mathrm{Rh})$ and the difference between $\mathrm{NPP}$ and $\mathrm{Rh}$ is the Net Ecosystem Production

$$
\mathrm{NEP}=\mathrm{NPP}-\mathrm{Rh}=\mathrm{GPP}-\mathrm{TER}
$$

The NEP represents the net ecosystem carbon sink or source due to physiological processes and it is also named Net Ecosystem Exchange (NEE) when it is quantified using measurements of $\mathrm{CO}_{2}$ exchanges between ecosystem and atmosphere (while it is called NEP when measured using inventory approaches). The two terms are somehow interchangeable but in general with opposite signs: a flux of carbon from the atmosphere to the ecosystem is positive in NEP and negative in $\mathrm{NEE}$. The sum of the two respiration components ( $\mathrm{Rh}$ and $\mathrm{Ra}$ ) represents the total ecosystem respiration (TER).

The NEP is however different from the long term carbon balance of the ecosystem because there can be changes in the carbon stocks due to episodic losses by natural or anthropogenic disturbances and management practices. For this reason the Net Biome Production (NBP) is defined as (Schulze et al. 2000):

$$
\mathrm{NEP}=\mathrm{NPP}-\mathrm{CO}_{2} \text { losses due to disturbances }
$$

There are different possible approaches and methods to measure the fluxes of energy and greenhouse gases (GHGs) in terrestrial ecosystems, ranging from inventory approaches to chambers measurements and ecosystem scale techniques such as the Eddy Covariance method (Aubinet et al. 2012).

The Eddy Covariance methodology has been developed in the early '90s and has been widely applied at global level. It is based on high frequency $(10 \mathrm{~Hz})$ measurements of wind speed, temperature and gas concentration using a three-axis sonic anemometer (which measures the wind speed along the three axis) and a fast response gas analyzer, typically an Infra Red Gas Analyzer (IRGA) for $\mathrm{CO}_{2}$ and $\mathrm{H}_{2} \mathrm{O}$, even if new systems have been recently developed and commercialized to measure high frequency concentrations of other gases such $\mathrm{CH}_{4}, \mathrm{~N}_{2} \mathrm{O}$ and $\mathrm{O}_{3}$.

With the Eddy Covariance technique it is possible to measure the Net Ecosystem Exchange (NEE) of a GHG of a given surface extended around the monitoring tower (the footprint). The extension and shape of the footprint is function of the wind speed, wind direction and the difference between the measurement and canopy heights and it has generally a radius between few hundred meters and one kilometer around the measurement point. The Eddy Covariance technique is the only method available today to continuously measure the net ecosystem exchanges at ecosystem level and in a not-destructive way.

In addition, for $\mathrm{CO}_{2} \mathrm{NEE}$ measurements, there is the possibility to statistically partition the net carbon fluxes measured into its major components as the gross primary production (GPP) and the ecosystem respiration (Reichstein et al. 2005; Lasslop et al. 2010) allowing a better interpretation of the fluxes in terms of ecosystem processes.

Nowadays, more than 500 sites exist globally, organized in regional networks contributing to the global network FLUXNET (http://fluxnet.ornl.gov/) with the 
aim to create global standardized datasets of Eddy Covariance measurements available to the scientific community (Papale et al. 2012). The usefulness of these measurements has been proved by the large range of applications published in the last years, ranging from empirical up scaling (Jung et al. 2010; Beer et al. 2010) to climate-ecosystem interactions (Reichstein et al. 2007), ecosystem functioning (Mahecha et al. 2010; Williams et al. 2012) and model and remote sensing products parameterization and validation (Maselli et al. 2009; Chiti et al. 2010; Migliavacca et al. 2011; Wang et al. 2012).

\subsection{The Italian Network}

In Italy the first sites measuring $\mathrm{CO}_{2}$ and $\mathrm{H}_{2} \mathrm{O}$ fluxes continuously using the Eddy Covariance technique were started in 1996-1997 (IT-Cpz, IT-Col and IT-Ren) within the context of the EUROFLUX European project (ENVCT 0095-0078), but the number increased rapidly in the following years thanks to other European research projects supporting the continental network of sites.

The CarboItaly FISR Italian project offered the opportunity to consolidate, enlarge and standardize the Italian network of sites which amounted to 29 sites in the 2007-2010 period. These sites, representing different Plant Functional Types (PFTs) and distributed along the Italian peninsula (Fig. 2.1), are briefly described in the following subsections. The network has been coordinated by the University of Tuscia, also hosting the database where all the data have been processed, stored and are today available to its users.

The data measured with the Eddy Covariance technique need a multiple-steps processing that, in particular for $\mathrm{CO}_{2}$ and $\mathrm{H}_{2} \mathrm{O}$, has been standardized and consolidated also during the CarboItaly project. The developed processing chain is applicable to all those sites minimizing potential differences due to the data Quality assurance/Quality control (QA/QC) used in particular when synthesis activities involving multiple sites are performed. The measurements acquired by the Italian sites have all been centrally processed according to the international standards described in Papale et al. (2006), Moffat et al. (2007) and Reichstein et al. (2005).

\subsubsection{Amplero (IT-Amp)}

The Amplero Mediterranean mountainous grassland is located in central Italy in the Abruzzo region $\left(41.90409^{\circ} \mathrm{N} ; 13.60516^{\circ} \mathrm{E}\right)$ on a flat to gently south sloping (2-3\%) area, at 884 m.a.s.l. The experimental area is a homogenous mixed grassland, mainly composed by few dominant graminoids (genus Poa $10 \%$ ), forbs (genus Trifolium $30 \%$, genus Medicago $20 \%$ ) and composites (genus Geranium $20 \%$, genus Cerastium $20 \%$ ). The growing season ranges from April to the end of May (roughly 60 days long) with the maximum of production at the end of May, while the 


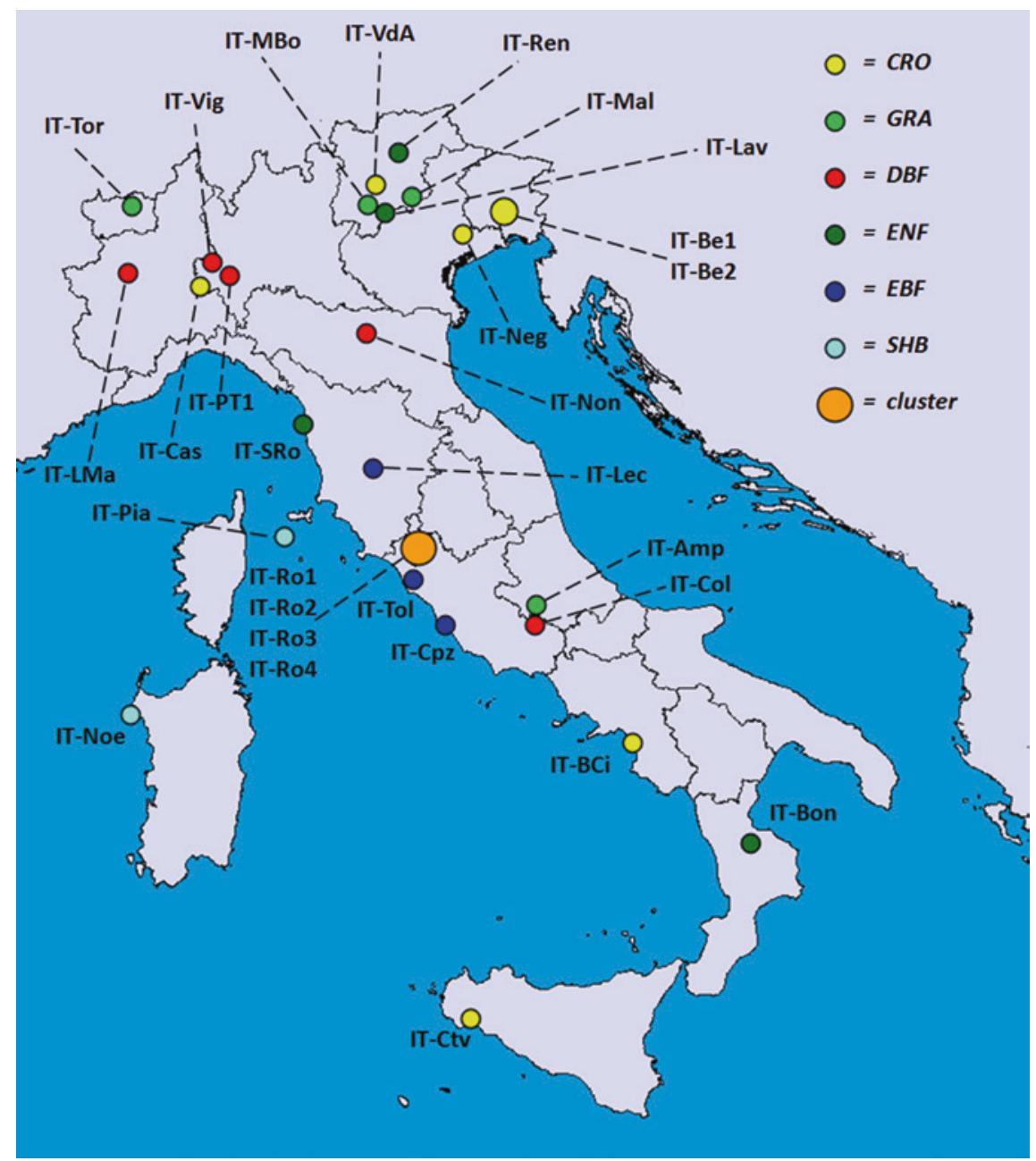

Fig. 2.1 Map of the Italian Eddy Covariance sites contributing to the Carboltaly project. Colors represent the different PFTs: $C R O$ cropland, GRA grassland, DBF deciduous broadleaf forest, $E N F$ evergreen needleleaf forest, $E B F$ evergreen broadleaf forest, $S H B$ shrubland. The Roccarespampani cluster includes two $D B F$ and two $C R O$ sites

senescence occurs in June. At the end of June there is a clip and after that the animal grazing (cows, horses and donkeys) until the end of November. The estimated stoking rate is around 0.5-1 animals per hectare each year and we can therefore assume that the grazing is extensively managed. The climate of this area is mountainous Mediterranean (Petriccione et al. 1993), typical climate of the Italian Apennines region. Average annual precipitation is 1,365 mm (ARSSA local database) with two precipitation peaks: one in autumn (October to December) and the other one in spring (March to April). The precipitation minimum occurs in July. The soil is Haplic Phaeozems 
(FAO 2008) with a depth of more than $1 \mathrm{~m}$ and drainage from poorly to imperfectly. The percentage of clays is $56 \%$ and $\mathrm{pH}$ is 6.5 . Roots reach down to $30 \mathrm{~cm}$ and more than $90 \%$ of roots is placed in the first $15 \mathrm{~cm}$. Starting from the last 50 years the area has been managed by a combination of clipping/harvesting and cattle grazing. The Eddy Covariance flux tower has been installed in June 2002 and the measurements have been carried out until July 2008 (Gilmanov et al. 2007; Wohlfahrt et al. 2008).

\subsubsection{Beano (IT-Be1 and IT-Be2)}

An agricultural field of 13.3 ha was selected in the north-eastern part of Italy in the late autumn of 2006. In this field, irrigated maize (Zea mays L.) was cultivated during the last 30 years and the soil was tilled using a winter plow to a depth of $0.35 \mathrm{~m}$ and a spring soil preparation $(5 \mathrm{~cm})$ prior to sowing. A quite constant high yield (10-11 $\mathrm{Mg} \mathrm{ha}^{-1}$ dry matter) was achieved using a sprinkler irrigation system and adding chemical fertilizers used in accordance with standard practices. The average annual temperature at the site was $13.7{ }^{\circ} \mathrm{C}$ and annual precipitation was around 1,200 mm (2000-2007). Soil can be classified as a Chromi-Endoskeletic Cambisol (FAO 2008) with the following characteristics in the $0-30 \mathrm{~cm}$ horizon: total $\mathrm{SOC}=48.4 \pm 8.5 \mathrm{Mg} \mathrm{C}^{-1}$, total $\mathrm{N}=4.2 \pm 1.1 \mathrm{MgN} \mathrm{ha}^{-1}$, soil bulk density $=1.25 \pm 0.15 \mathrm{~g} \mathrm{~cm}^{-3}$, soil field capacity $=23 \% \mathrm{v} / \mathrm{v}$, wilting point $=12 \%$ $\mathrm{v} / \mathrm{v}$ and $\mathrm{pH}=7.1 \pm 0.02$ (Alberti et al. 2010). The study area was divided into two sections obtaining an eastern area of 8.6 ha and a western area of 4.7 ha. Maize was cultivated in the East field (IT-Be1, 46.00361 ${ }^{\circ} \mathrm{N} ; 13.0256^{\circ} \mathrm{E}$ ) using similar management practices described above. After harvest, grain was removed from the field while residues were left there (harvest index: $50 \%$ ). Instead, the West field (IT-Be2, $46.00431^{\circ} \mathrm{N} ; 13.02776^{\circ} \mathrm{E}$ ) was converted to fodder alfalfa (Medicago sativa L.), with a late winter plowing at $0.35 \mathrm{~m}$ (February 2007). At sowing, $39 \mathrm{~kg} \mathrm{ha}^{-1}$ of seeds were used. No $\mathrm{N}$ fertilization was performed in IT-Be2. Alfalfa was maintained from 2007 to 2009 with an average of four harvests during summer. In 2010 , IT-Be2 was converted again to maize with a minimum tillage $(0-5 \mathrm{~cm})$ before sowing and following the same management practices used in IT-Be1.

\subsubsection{Bonis (IT-Bon)}

The experimental site is located in Southern Italy, in the Sila Greca mountain range, in the region of Calabria $\left(39.47778^{\circ} \mathrm{N} ; 16.53472^{\circ} \mathrm{E}\right)$. The watershed area is 140 ha, ranging from 975 to 1,300 m.a.s.l. and has been reforested between 40 and 50 years ago with conifers (Pinus nigra J.F. Arnold subsp. laricio, $80 \%$ ) and broad-leaves (Castanea sativa L., $6 \%$ ). The remaining surface is covered by pastures, crops, creeks and bare soil. The area is characterized by a Mountain Mediterranean climate with variable but generally sufficient rainfall $(1,170 \mathrm{~mm})$ 
and an average temperature of $8.7^{\circ} \mathrm{C}$. Since 1986 , the watershed has been equipped with meteorological stations and instrumentation in order to monitor hydrometrical heights and river discharge. Components of the hydrological balance are studied since 1994 in forest structures characterized by different thinning regimes. Since 1999, the effect of different fire types on soil erosion and hydrology is also studied. The flux stations have been established in 2003 over 35 years-old pine plantation

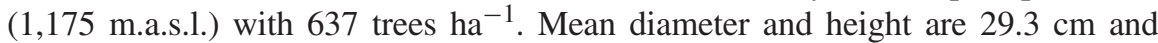
$20 \mathrm{~m}$, respectively, with a basal area of $45.4 \mathrm{~m}^{2} \mathrm{ha}^{-1}$. In 2006, all sided Leaf Area Index (LAI) was $6.55 \pm 0.18$. Substrate is granite and soils are Ultic Haploxeralfs.

\subsubsection{Borgo Cioffi (IT-BCi)}

The Borgo Cioffi monitoring site has been running since July 2002 on a arable field located on Gaetano Iemma's farm (Eboli, Salerno, 40.52375 ${ }^{\circ} \mathrm{N} ; 14.95744^{\circ} \mathrm{E}$ ), covering a total area of 150 ha in the centre of the Sele river Plain, an alluvial plain featuring an intensive and high income agricultural activity. The station is located about 20 m.a.s.l., which can be found south-west at a distance of about $5 \mathrm{~km}$. The 16 ha field, in which all the experimental activities are carried out, is surrounded by irrigated land, has no aerodynamic obstacles in the vicinity of the boundaries able to influence the vertical profiles of atmospheric properties and it is irrigated by means of an automatic central pivot system.

The farm hosts a water buffalo operation with over 800 adult cattle, and the fields have been cultivated for decades to forage crops (alfalfa, winter and spring grass, corn silage) and winter vegetables (fennel, cauliflower). Solid and liquid manure are frequently applied at high rates.

The station is located approximately in the centre of the field, featuring an approximately rectangular shape with sides of 270 and $600 \mathrm{~m}$. The fetch in the prevailing wind directions, south-west and north-east, is about $200 \mathrm{~m}$. The slope is almost flat with a $2 \%$ downward gradient towards the south.

The soil, classified as a Calcic Kastanozem Skeletic (FAO 2008) and derived from calcium carbonate parent rock, boasts an alluvial origin and features a siltclay texture.

\subsubsection{Castellaro (IT-Cas)}

The site is located in Lomellina, a typical rural area of the Po Valley in Northern Italy, in the municipality of Torre Beretti and Castellaro (Pavia) $\left(45.07005^{\circ} \mathrm{N}\right.$; $8.71752^{\circ} \mathrm{E}, 88 \mathrm{~m}$.a.s.1.). The field extends for $400 \times 700 \mathrm{~m}$ and it has been cultivated with hybrid corn (Zea mais L., variety pioneer for silage production) in 2006 and with rice from 2007 to 2010. The rice cultivar was Balilla (japonica rice short grain), a typical management cycle starts with $25 \mathrm{~cm}$ deep ploughing in January, 
laser soil leveling in February, in March sugar beet industrial slops $\left(2,250 \mathrm{~kg} \mathrm{ha}^{-1}\right)$ and urea $\left(75 \mathrm{~kg} \mathrm{ha}^{-1}\right)$ are incorporated and compacted before sowing in April into water with $210 \mathrm{~kg} \mathrm{ha}^{-1}$ of seed. Weed control in May, top dressing with Urea $\left(90 \mathrm{~kg} \mathrm{ha}^{-1}\right)$ in June. The average depth of standing water was maintained at about $5 \mathrm{~cm}$ in 2007 and $10 \mathrm{~cm}$ in 2008. The standing water level fluctuates during the flooded periods due to the continuous water flow through the rice field, a typical management practice for this crop. At the beginning of September the water is removed from the field and the harvest takes place in October. The final rice production was about 9 tree $\mathrm{ha}^{-1}$. The soil originating from fluvial deposits is poorly drained and characterized by a ground water table very close to the surface. In most parts of the field it is a Calcic Gleysol (FAO 2008), with a loam to clay-loam texture, in other parts of the field we find Haplic and Mollic Gleysols. The A-horizon shows $\mathrm{pH}\left(\mathrm{H}_{2} \mathrm{O}\right)$ values ranging at 6.4-7.1, the organic carbon content is between 1.6 and $2.4 \%$. The gleyic color pattern of soil materials indicates dominant water saturation for most of the year in combination with poor drainage due to cultivation tillage and agricultural practices. During the observation period the average annual rainfall was $704 \mathrm{~mm}$ while the average annual temperature was $13.0^{\circ} \mathrm{C}$.

\subsubsection{Castelvetrano (IT-Ctv)}

The site is an olive orchard (cv. Nocellara del Belice) located in western Sicily at Castelvetrano $\left(37.64416^{\circ} \mathrm{N} ; 12.84638^{\circ} \mathrm{E}\right)$. The orchard has an extension of about 11 ha and has four different plots characterized by trees of different age (75 \% 12-16 years old, $25 \% 150$ years old) but similar LAI (2.6-3.4) and trees height (3.4-3.7 m).

The soil texture is clay-loam with a volumetric water content at a field capacity of 36.1 and $17.4 \%$ at $-1.5 \mathrm{MPa}$ soil water potential.

All of the plots were equipped with an irrigation system characterized by two micro sprinklers ( 8 liters hour ${ }^{-1}$ ) per tree. During the vegetative season, the total volume of water varied between 1,500 and $2,000 \mathrm{~m}^{3}$ ha depending on summer weather conditions. In accordance with the cultural practice adopted in this traditional olive-growing area, soil is clean cultivated during the vegetative season, whereas no weed control is undertaken during the rain season (autumn and winter).

The adopted tillage in the soil during the year allowed the growth of spontaneous annual herbaceous crops, characterized by the prevailing presence of grass (Graminaceae spp).

\subsubsection{Castelporziano (IT-Cpz)}

The experimental site was a 60 years-old coppice under conversion to high forest, inside the Presidential Reserve of Castelporziano $\left(41.70525^{\circ} \mathrm{N} ; 12.37611^{\circ} \mathrm{E}\right.$ ), 2.8 m.a.s.1., $25 \mathrm{~km}$ West of Rome. The natural Reserve covers about 4,800 ha, of 
which $85.6 \%$ are forests. The climate is Mediterranean Type humid sub humid with an average yearly rainfall of $780 \mathrm{~mm}$ and an air temperature of $15.6^{\circ} \mathrm{C}$.

The forest structure is characterized by two layers: a dominant layer of Quercus ilex L. 12-15 m high and a shrub layer, 2-4 m high, with Phillirea latifolia L. Pistacia lentiscus L., Erica arborea L., Cistus salvifolius L.,Cistus incanus L., Cytisus scoparius L., and some vines (Clematis flammula L., Hedera helix L., Rubia peregrina L., Smilax aspera L.). Large trees over 100 years old, and up to $17 \mathrm{~m}$ high and $170 \mathrm{~cm}$ in diameter, represent only $1 \%$ of the stand. LAI is in between 3.2 and 3.8. The herbaceous layers are represented by Brachipodium sylvaticum (Hudson) Beav., Cyclamen repandum Sibth et Sm., Carex distachya Desf., Asperula laevigata L., and Alliaria petiolata Bieb. The current $Q$. ilex forest represent a secondary succession after a fire destroyed the area in 1944. In 1985 the stand was converted from coppice into high forest.

The morphology of the reserve is mostly flat with altitudes ranging between 0 and 85 m.a.s.l. The soil is $40-60 \mathrm{~cm}$ deep with a pH 5.8 and the profile of the experiment is type A-C, with a fairly deep, well draining A horizon, rich in humus and calcium carbonate. The soil is sandy $(75.2 \%$ coarse sand, $11.2 \%$ fine sand, $3.7 \%$ coarse silt, $2.2 \%$ fine silt, and $6.7 \%$ clay). The soil organic matter is $3.4 \%$ between 0 and $20 \mathrm{~cm}$ and $1.1 \%$ between 20 and $40 \mathrm{~cm}$. Organic carbon is $1.9 \%$ in the organic horizon with a $\mathrm{C} / \mathrm{N}$ ratio of 66 and is $0.65 \%$ with a $\mathrm{C} / \mathrm{N}$ ratio of 100 in other mineral Horizons.

The climate is characterized by a dry season extending for 4 months, from the beginning of May to the end of August. Water deficit during the dry seasons is $406 \mathrm{~mm}$, while excess rainfall in other seasons is $410 \mathrm{~mm}$. The scattered low summer rains are offset by high night humidity, which over a period of 10-15 days can contribute to $0.2-0.8 \mathrm{~mm}$ of precipitation.

\subsubsection{Collelongo (IT-Col)}

The experimental site is located near the village of Collelongo, Abruzzo region, in central Italy, close to the external belt of the Abruzzo, Lazio and Molise National Park. The Selva Piana forest stand $\left(41.84936^{\circ} \mathrm{N} ; 13.58814^{\circ} \mathrm{E}, 1,560\right.$ m.a.s.l.) belongs to a 3,000 ha forest community which is part of a wider forest area. The environmental and structural conditions of the stand are representative of central Apennines beech forests. The site was established in 1991 to study ecology and silviculture of Apenninian beech (Fagus sylvatica L.) forest. In 1993, the site was the first European forest to be instrumented to measure ecosystem level fluxes with Eddy Covariance (Valentini et al. 1996). In 1995-1996, the area became an ICP-Forests level II and an ICP-IM monitoring plot (http://icp-forests.net/). Since 2006, the site has become one of the main stations of the Long-Term Ecological Research site "Forests of the Apennine". Over the years, the site was included in several EU and national research, monitoring and environmental projects. It is a pure beech forest with 830 trees ha ${ }^{-1}$, with an average diameter of $22 \mathrm{~cm}$ and an average height of $21.5 \mathrm{~m}$. The average tree age is approximately 120 years (2011). LAI ranges between 4.5 and 6.2 (1992-2011). Aboveground 
and belowground biomass is $171 \mathrm{Mg} \mathrm{C} \mathrm{ha}^{-1}$. The $40-100 \mathrm{~cm}$ deep soil is developed on calcareous bedrocks and is classified as humic alisol. Mineral soil carbon stock $(0-80 \mathrm{~cm})$ is $223 \mathrm{Mg} \mathrm{C} \mathrm{ha}^{-1}$, with $4.4 \mathrm{Mg} \mathrm{C} \mathrm{ha}^{-1}$ stocked as litter (OL layer). The climate at the site is Mountain-Mediterranean with an average annual temperature of $6.9{ }^{\circ} \mathrm{C}$ and an average annual precipitation of $1,230 \mathrm{~mm}$. Snow cover can last from mid December to mid March-early April.

\subsubsection{La Mandria (IT-LMa)}

The tower site $\left(45.15258^{\circ} \mathrm{N} ; 7.58259^{\circ} \mathrm{E}\right)$ is included into La Mandria regional park which has an extension of 3,000 ha and is located in the suburbs of Turin, near Venaria Reale, at about 350 m.a.s.1. The area is typical for peculiar geomorphic features originated by the presence of old terraces, residual of the ancient level of the main plain, which forms a hilly landscape with highlands and valleys, connected by steep slopes and characterized by regressive erosion of small rivers.

Vegetation is mainly constituted by the oak-hornbeam (Quercus robur L. and Carpinus betulus L.) of the high plains, which is considered an important forest-type to be studied and conserved. In the park there are also some plantations of red oaks (Quercus rubra L.), which cover around $20 \%$ of the woods, some Robinia psuedoacacia formation on the slopes, some grasslands and poplar formations on the plains. Age of the oak-trees is about 80 years in average but an increase of trees mortality is registered along with wildlife high pressure which stops plant regeneration.

The soil on the top of the terraces is mainly 'paleosols', which according to the USDA classification are called Typic Fragiudalf, fine-silty, mixed, acid, mesic. One of the main features of the soil profile is connected to a temporary groundwater, placed at 60-70 $\mathrm{cm}$ below the ground level and a top-layer rich of silt, above a sub-layer called 'fragipan' which is very hard to root penetration. Therefore trees tend to stay with their root-apparatus within the upper part of the soil profile, often increasing the chances of tipping. Moreover, the greatest percentage of biological activity is detected in the topsoil, due to the difficulties of organic matter to deepen below the ground water zone.

Climate is classified as humid (second mesothermic with a low summer efficiency) with an annual rainfall of $1,030 \mathrm{~mm}$ and an annual temperature of $11.6{ }^{\circ} \mathrm{C}$. The stand in the surrounding area of the flux tower has a measured biomass of $14 \mathrm{~kg} \mathrm{~m}^{-2}$, a leaf litter of $1.4 \mathrm{~kg} \mathrm{~m}^{-2}$ and a tree density of $311 \mathrm{ha}$.

\subsubsection{Lavarone (IT-Lav)}

The Lavarone station is situated in the south east of the Trento province $\left(45.95620^{\circ} \mathrm{N}\right.$; $11.28132^{\circ} \mathrm{E} ; 1,300$ m.a.s.l., average annual temperature $7.2{ }^{\circ} \mathrm{C}$, total annual precipitation $1,150 \mathrm{~mm}$ ) on a mountain plateau ranging from 1,000 to 2,000 m.a.s.1. 
The whole study area covers nearly $80 \mathrm{~km}^{2}$. This composite landscape is still widespread in the southern Alps, although it is undergoing a rapid transformation because of the combined effect of land use intensification in some more productive areas and the abandonment of more marginal ones. The landscape is characterized by the spatial succession of the three typical mountain management systems: grasslands (Arrenatheretum), pastures (Festucaetum) and mixed coniferous and broadleaf forests (Abietis-fagetum). The area analysed is characterized by an uneven-aged mixed forest dominated by Abies alba Mill. (70 \%), Fagus sylvatica L. (15\%) and Picea abies (L.) H.Karst (15\%), with an average of 1,300 stems ha ${ }^{-1}(\mathrm{dbh}>7.5 \mathrm{~cm})$ and a LAI of 9.6. The canopy has a dominant layer reaching 33-38 $\mathrm{m}$ and crown lower limits at about $12 \mathrm{~m}$. In the understorey suppressed beeches form a discontinuous second layer from 0 to $4 \mathrm{~m}$. The site is located on a gently rolling karst plateau and has a homogeneous vegetated fetch larger than $1 \mathrm{~km}$ in all directions, except for a $45^{\circ}$ sector (300 $\mathrm{m}$ fetch in the SSW direction). Soils are generally well developed brown earth lying on a calcareous bedrock with the following characteristics in the $0-30 \mathrm{~cm}$ horizon: total $\mathrm{SOC}=11.8 \pm 1.8 \mathrm{~kg} \mathrm{C} \mathrm{m}^{-2}$, total $\mathrm{N}=0.61 \pm 0.05 \mathrm{~kg} \mathrm{~N} \mathrm{~m}^{-2}, \mathrm{CN}$ ratio $=15.9 \pm 1.0$.

\subsubsection{Lecceto (IT-Lec)}

Lecceto forest $\left(43.30359^{\circ} \mathrm{N} ; 11.26975^{\circ} \mathrm{E}\right)$ is a Holm oak coppice with a shift of 18-20 years located South-East of Siena, near the centre of the region of Tuscany, at about 300 m.a.s.l. It is the residual part of a broader forest named Selva del Lago for its proximity, during the Middle Ages, to a marshy area, subsequently drained in the XVIII century. That forest covered a surface of $10 \mathrm{~km}$ from north to south and $7 \mathrm{~km}$ from east to west. Because of the large use of wood during the Middle Ages, the Selva del Lago forest was subjected to specific rules of management and became a crucial crossroad between surrounding rural communities. In the XI century the most important Augustinian hermitage of Siena territory was founded in the middle of the forest. Since 1972 the hermitage was turned into a monastery of Augustinian cloistered nuns.

The forest covers an area of 900 ha and Holm oak represents $81 \%$ of the total tree canopy; others species are represented by Arbutus unedo L., Juniperus communis L., Quercus pubescens L., Phillyrea latifolia L., Fraxinus ornus L.

The soil of the site is rocky and shallow, characterized by metamorphic schists and anagenite, and secondarily by cavernous limestone and carsism phenomena. The climate of Lecceto is a Mediterranean one, characterized by a strong seasonality with rainfall concentrated in autumn-winter, high inter-annual variability and frequent extreme events, such as summer drought and heatwaves. The average cumulated annual precipitation (1961-1990) at the nearest rain gauge is $780 \mathrm{~mm}$, with a minimum in July $(29 \mathrm{~mm})$ and a maximum in November $(108.7 \mathrm{~mm})$; average annual temperature is $13.5^{\circ} \mathrm{C}$; July is the hottest month and January the coldest. 
The stand in the surrounding area of the flux tower was coppiced about 15 years ago; its average stand height is around $9 \mathrm{~m}$ and the density of the stumps is about $1,200 \mathrm{ha}^{-1}$.

\subsubsection{Malga Arpaco (IT-Mal)}

Tesino Upland is located in the eastern part of Valsugana, in the southern part of external Dolomites; its Northern border is marked by the Lagorai mountains $(2,700 \mathrm{~m})$. The study site is located on a farm (Malga Arpaco) at 1,730 m.a.s.l. $\left(46.11402^{\circ} \mathrm{N} ; 11.70334^{\circ} \mathrm{E}\right)$, near Passo Brocon, it is a seasonality pasture (alpeggio) with pasture times from the beginnings of June to the end of August (around 100 days). The climate in the southern part of Dolomites is influenced by the Adriatic sea, while in the northen part it is more continental; the annual rainfall is about 1,100-1,550 mm concentrated in spring (May-June) and in autumn (OctoberNovember); the average temperature is lower than $0{ }^{\circ} \mathrm{C}$ from December to March.

The examined pasture is in the inferior alpine horizon. This vegetation layer is the upper limit of the microtherrmal Fagus forest and it may be constituted by Picea in the lower part and by Larix in the higher part. In this area, human activity changed the original vegetation to pastures and grasslands by cutting the forests, while in other sites the alpine pastures are typically above the upper tree vegetation line. The soil is an alfisol, sandy-loam and a Typic Hapludalfs (FAO 2008).

The Malga Arpaco pasture results to be sufficiently used, without bushes, pasturing paths, erosion; yet, the negative effects of understocking begin to appear, as evidenced by the existence of some limited overpastured areas surrounded by Deschampsia spp. and Cirsium spp.

From the floristic survey the grassland resulted to be composed predominantly by good fodder Poaceae (genera Festuca, Poa, Phleum), reduced by pasturing in summer; yet, the area shows, at least in some parts, the specific composition of a mid-damp and degraded grassland, with nitrophilous species, and the signs of a strong use, in transition from a grassland to an unrationally grazed pasture.

\subsubsection{Monte Bondone (IT-MBo)}

The study site was located at 1,550 m.a.s.l. on a mountain plateau in the Italian Alps (Viote del Monte Bondone, $46.01468^{\circ} \mathrm{N} ; 11.04583^{\circ} \mathrm{E}$ ). The average annual air temperature is $5.5^{\circ} \mathrm{C}$ with monthly averages ranging from $-2.7^{\circ} \mathrm{C}$ in January to $14.4{ }^{\circ} \mathrm{C}$ in July. The average annual rainfall is $1,189 \mathrm{~mm}$, with peaks in June (132 mm) and October $(142 \mathrm{~mm})$; snow cover occurs between November and April. The area is managed as an extensive meadow dominated by Festuca rubra L. (basal cover of $25 \%$ ), Nardus stricta L. (basal cover of $13 \%$ ) and Trifolium sp. (basal cover of $14.5 \%$ ), which represents a typical low productivity meadow of the alpine region. The maximum canopy height at the peak of the growing 
season (mid June to early July) can reach up to $30 \mathrm{~cm}$. Meadows represent the main land use on this plateau $\left(2 \mathrm{~km}^{2}\right)$ and are traditionally managed for hay production with low mineral fertilization and one cut per year in mid-July. Soil can be classified as a Typic Hapludalfs, lyme loamy, mixed, mesic with the following characteristics in the $0-30 \mathrm{~cm}$ horizon: total $\mathrm{SOC}=9.4 \pm 0.4 \mathrm{~kg} \mathrm{C} \mathrm{m}^{-2}$, total $\mathrm{N}=0.29 \pm 0.02 \mathrm{~kg} \mathrm{~N} \mathrm{~m}^{-2}$, soil bulk density $=0.79 \pm 0.29 \mathrm{~g} \mathrm{~cm}^{-3}$.

\subsubsection{Negrisia (IT-Neg)}

The site is located in North-Eastern Italy in a commercial vineyard located in Negrisia di Ponte di Piave (45.74756 ${ }^{\circ}$ N; $12.44673^{\circ}$ E, 11 m.a.s.l.). The climate is mediterranean, with average annual precipitations of $833 \mathrm{~mm}$ and an average annual temperature of $13.1{ }^{\circ} \mathrm{C}$. The station, set up in July 2005 , is in the center of a one single 25 ha plot. The terrain is quite flat and both soil and canopy are very homogeneous and thus suitable for both micrometeorological and remote-sensing approaches. The vineyard is mainly composed of Vitis vinifera L. cv. 'Carmenère N.' grafted on $\mathrm{SO}_{4}$ rootstock. The vines were planted in 1992 in north-south oriented rows (500-600 m long) $2.50 \mathrm{~m}$ apart. Plant spacing on the rows is $1.30 \mathrm{~m}$, resulting in a density of 3,076 vines per hectare. Vines were grown with a single trunk trained to spur-pruned cordon, at about $1.7 \mathrm{~m}$ aboveground, for vertical shaker harvesting. The floor is grass covered and a $1 \mathrm{~m}$ wide strip on the rows is chemically treated. The silty-clay loam soil (International textural classes), classified as Vertic Eutrudent (FAO 2008), is $>1 \mathrm{~m}$ deep and highly homogeneous within the study site, rich in organic matter (about $18.2 \mathrm{~g} \mathrm{~kg}^{-1}$ ) and with an average $\mathrm{pH}$ of 7.7. The vineyard receives standard management. Maximum canopy height was kept at $2.70 \mathrm{~m}$, and no foliage could be found below the cordon. Maximum LAI, monitored both by direct and by indirect methods, ranges from 2.2 to 2.5 .

\subsubsection{Nò̀ (IT-Noe)}

The Noè site is located within a nature reserve called "Le Prigionette" $\left(40.60613^{\circ}\right.$ $\mathrm{N} ; 8^{8} 15146^{\circ} \mathrm{E}, 27$ m.a.s.l.). The area is part of the Capo Caccia peninsula, in North-Western Sardinia, near the town of Alghero. The nature reserve, with a surface area of approximately 1,200 ha, is delimited by a cliff dropping to the sea on the north-western and western boundaries.

The climate is Mediterranean, semiarid with a warm summer, mild winter, and a prolonged water shortage from May through September. The averages for annual, minimum and maximum temperatures are respectively 15.9, 7.0, and $28.0{ }^{\circ} \mathrm{C}$. The average annual thermal excursion is about $14{ }^{\circ} \mathrm{C}\left(10^{\circ} \mathrm{C}\right.$ in January and $24{ }^{\circ} \mathrm{C}$ in August). The average annual precipitation is $588 \mathrm{~mm}$, mainly concentrated during the spring season. In the course of the autumn intense rainstorms often occur with high runoff and low water storage. 
The main species are juniper (Juniperus phoenicea L.), lentisk (Pistacia lentiscus L.), tree phyllirea (Phyllirea angustifolia L.), and dwarf fan palm (Chamaerops humilis L.). These species form a sparsely vegetated shrub land, where juniper and lentisk, which respectively cover 53 and $22 \%$ of the vegetated surface, are aggregated into variably-sized patches with bare ground in between. Phillyrea and palm can only be found as isolated elements inside the main patches. Other species typical of Mediterranean maquis are present on the experimental site: rosemary (Rosmarinus officinalis L.), Genista corsica (Loisel) DC., Daphne gnidium L., Smilax aspera L., Euphorbia characias L., Helichrysum microphyllum DC., Asphodelus microcarpus Salzm., and Ferula communis L. The vegetation is a secondary succession following a fire event occurred in 1963 and agricultural abandonment in 1970. Currently, this area has limited human activity. The average maquis height ranges between 0.93 and $1.43 \mathrm{~m}$, and the ground cover varies between 42 and $91 \%$. Total LAI values range from 2.7 to 3.0. The soil is Lithic Xerorthent, $0.3-0.4 \mathrm{~m}$ deep, mainly composed of clay, and erosion is common.

\subsubsection{Nonantola (IT-Non)}

The Nonantola forest is a hardwood plantation located in a flat rural area of the Po valley in the Emilia Romagna region, close to Modena $\left(44.69019^{\circ} \mathrm{N} ; 11.09109^{\circ} \mathrm{E}\right.$ 15 m.a.s.1.). The site was set up in 1992 with European fundings (Set-aside, Reg. CEE $797 / 85$ and, being a re-forestation in a former rural area it is a proper representation of a Kyoto forest-Sect. 3.3 of the Kyoto Protocol). The forest is still growing and has not yet reached the final stage, its dominant species consisting of: Oak (Quercus robur L.) $35 \%$, Ash (Fraxinus spp.) $25 \%$, Maple (Acer campestre L.) $12 \%$, Willow (Salix alba L.) $8 \%$, Poplar (Populus alba L.) $6 \%$, Cerry (Prunus mahaleb L.), other $8 \%$. The total area is 38.6 ha with a tree density of 1,100 trees $^{-1}$ at the plantation stage, and reduced to 826 trees ha ${ }^{-1} 10$ years after. The soil, by Soil USDA Taxonomy is Fine, Mixed, Mesic Entic Chromusterts with a $60 \%$ of clay, and a soil organic matter (SOM) of $49.8 \mathrm{Mg} \mathrm{C}^{-1}$ estimated in 1992 and $53.7 \mathrm{Mg} \mathrm{C}^{-1}$ measured in 2000. The average annual temperature of $13.1{ }^{\circ} \mathrm{C}$ and the average annual rainfall of $719 \mathrm{~mm}$. characterize the site as located in Mediterranean climate, with rainfall concentrated in autumn-winter, summer drought and some heat waves events. Fluxes have been measured since 2001 by means of the Eddy Covariance system placed at $13 \mathrm{~m}$ above the forest floor and steadily to rise during tree increase.

\subsubsection{Parco Ticino (IT-PT1)}

The study site is located at 60 m.a.s.l., about $10 \mathrm{~km}$ North-West of the city of Pavia $\left(45.20087^{\circ} \mathrm{N} ; 9^{9} 06104^{\circ} \mathrm{E}\right)$ in the municipal area of Zerbolò, within the Ticino Natural Park in Northern Italy. Poplar land-use was introduced in the area after 1973 when a fire destroyed the foregoing natural land cover, a floodplain forest with dominant oak 
(Quercus robur L.), ash (Fraxinus excelsior L.), white poplar (Populus alba L.) and black alder (Alnus glutinosa (L.) Gaertn). A relict of the natural forest is represented by the 200 year-old Bosco Siro Negri located within $1 \mathrm{~km}$. The poplar high stand of 46 ha (Populus $\times$ canadensis Moench, Clone I-214) was 12 years old in 2002, the spacing was $6 \times 6 \mathrm{~m}$ and the tree density was 278 tree ha $^{-1}$. The average tree height was $26.6 \mathrm{~m}$, while the average diameter at breast height (dbh) was $0.33 \mathrm{~m}$ and the stem basal area was $20.5 \mathrm{~m}^{2} \mathrm{ha}^{-1}$ in 2005 , when the site was logged. In order to carry out replanting after logging, residues were removed, stumps were drilled to allow a $60 \mathrm{~cm}$ deep ploughing, and $4 \mathrm{~m}$ long shoots were inserted for about $150 \mathrm{~cm}$ into the ground. In general, management intensity was low with removal of ground vegetation (mainly Artemisia and Poa) by harrowing during early summer and occasional irrigation on demand. During 2002-2005 one fertilization event of $300 \mathrm{~kg} \mathrm{ha}^{-1}$ of urea occurred in May 2002, and two natural flooding events in November 2002 and October 2004. Soils are Arenosols and Regosols not well developed on recent alluvial sand and gravel deposits of the Ticino river. Topsoil shows a bulk density of 0.9 $1.4 \mathrm{~g} \mathrm{~cm}^{-3}$, the nitrogen and carbon content are $5.23 \mathrm{~kg} \mathrm{C} \mathrm{m}^{-2}$ and $1.36 \mathrm{~kg} \mathrm{~N} \mathrm{~m}^{-2}$, $\mathrm{pH}\left(\mathrm{H}_{2} \mathrm{O}\right)$ ranges at 5.5-7.0. The soil texture is sandy-loam $(60.4 \%$ sand, $30 \%$ silt and $9.6 \%$ clay). The climate of the site is classified temperate continental, with an average annual rainfall of $912 \mathrm{~mm}$ and an average temperature of $12.5^{\circ} \mathrm{C}$. Budburst usually occurs at the beginning of April and senescence in October, with the LAI peaking at around 2.0 in July. Winds show a prevailing direction from the north-east and south-west. Atmospheric nitrogen deposition is about $20 \mathrm{~kg} \mathrm{~N} \mathrm{ha}^{-1}$ per year.

\subsubsection{Pianosa (IT-Pia)}

The Island of Pianosa $\left(42.58437^{\circ} \mathrm{N} ; 10.07804^{\circ} \mathrm{E}\right)$ is one of the seven islands of the Tuscan Archipelago with a total area of $10.2 \mathrm{~km}^{2}$ and a coastal perimeter of approximately $20 \mathrm{~km}$. The island is almost completely flat, with some small undulations, its highest elevation is 29 m.a.s.l., while the average is about 18 m.a.s.l. On the basis of a historical meteorological dataset (1951-2009), the average air temperature is $15.8{ }^{\circ} \mathrm{C}$ and the average annual rainfall is $497 \mathrm{~mm}$, ranging between a minimum of $176 \mathrm{~mm}$ (1999) and a maximum of $716.2 \mathrm{~mm}$ (1984). A clear seasonal precipitation pattern shows a maximum from October to December followed by a decrease with a minimum value in July. The soils are sandy-loam or sand, alkaline, rich in carbonates, with a moderate content of rock fragments, mainly classifiable as Leptosols. Three main ecosystems have been mapped: abandoned crops and pastures, Mediterranean macchia and woodlands. Abandoned croplands and pastures are the main ecosystems in terms of extent $(52 \%)$ but are less representative in terms of total biomass $(26 \%)$. The land previously used for agriculture is now covered by a species association typical of degraded Mediterranean agricultural soils. The Mediterranean macchia vegetation exists at different evolutionary stages as a consequence of the progressive re-naturalization process which the island is currently undergoing. The Island of Pianosa represents an interesting case study to assess the evolution related to land use change in a Mediterranean environment, since the island 
was intensively used for agricultural production presumably since the Romans. In particular, intensive soil cultivation was carried out by the prisoners of the local Penal Colony in the last century and subsequently abandoned at the end of the 1990s.

\subsubsection{Roccarespampani Forest (IT-Ro1 and IT-Ro2)}

The two sites, along with the IT-Ro3 and IT-Ro4 described below, are part of the Roccarespampani cluster within a publicly owned farm in the Province of Viterbo. The climate of the sites is typical Mediterranean, with dry and hot summers and relatively mild and wet winters. The average annual temperature is of $15{ }^{\circ} \mathrm{C}$ with a total rainfall of $800 \mathrm{~mm}$. The precipitation distribution pattern typically features a drought period in in the months of July and August. The bedrock is of volcanic origin and the soil is a $90 \mathrm{~cm}$ deep Luvisol (Tedeschi et al. 2006).

The Roccarespampani forest stretches for about 1,300 ha in a fairly flat area varying from 120 to 160 m.a.s.l. and it is mostly composed of Turkey oak (Quercus cerris L.) stands, historically managed under the silvicultural system of coppice-with-standards in the last 200 years with a rotation cycle ranging 15-20 years and it has been arranged in 15 sequentially aged compartments with an average area of 85 ha.

Eddy Covariance fluxes were monitored over two sites established in distinct compartments. The IT-Ro1 site $\left(42.40812^{\circ} \mathrm{N} ; 11.93001^{\circ} \mathrm{E}\right)$ operated in the period 2000-2009 and was representative for the initial developmental stages (0-9 years) of the forest after the forest cut (coppicing), which occurred in December 1999. The IT-Ro2 site $\left(42.39026^{\circ} \mathrm{N}, 11.92093^{\circ} \mathrm{E}\right)$ is instead representative of older stages (11 years) and it was set up in 2002. In terms of vegetation composition and structure, the earlier stages are characterized by a dense regrowth of shoots $(\sim 6,000$ trees $\mathrm{ha}^{-1}$ ) on coppiced stumps accompanied by shrubs such as Cytisus scoparius (L.) Link, Spartium junceum L., Crataegus spp., Paliurus spina-christi Mill., Rosa canina L., while oak standard trees in the range of 20-60 years $\left(\sim 100\right.$ trees ha $\left.^{-1}\right)$ tower over the low canopy. Later stages exhibit a less dense structure $\left(\sim 3,000\right.$ trees $\left.^{-1}\right)$ with a 16-20 m high main tree canopy, largely made up of $Q$. cerris, which includes also Quercus pubescens Willd., Fraxinus ornus L., Ulmus minor Mill., Ostrya carpinifolia Scop., Acer monspessulanum L. and A. campestre L. An understorey layer typically composed of Phillyrea latifolia L., Crataegus spp., Ruscus aculeatus L., Cornus spp., Prunus spinosa L., Sorbus spp. completes the forest vegetation (PGAF 2009).

\subsubsection{Roccarespampani Crops (IT-Ro3 and IT-Ro4)}

The sites are part of the Roccarespampani cluster (see Sect. 2.2.19) and were established in the late summer of 2007 in a flat, non-irrigated cropland. The two Eddy Covariance systems were installed in two adjacent arable fields $\left(42.37539^{\circ} \mathrm{N}\right.$; 
$11.91542^{\circ} \mathrm{E}$ for IT-Ro3 and $42.37333^{\circ} \mathrm{N} ; 11.91922^{\circ} \mathrm{E}$ for IT-Ro4). The two cropland fields are of about 15 ha each allowing a minimum distance of $110 \mathrm{~m}$ from the fields' edges, with surrounding fields being similarly covered by nonirrigated cropland. The soil is an Eutric Cambisol with a clay loam texture $(40 \%$ clay, $30 \%$ silt, $30 \%$ sand) and, on average, $10.8 \mathrm{~g} \mathrm{~kg}^{-1}$ of organic carbon and $1.3 \mathrm{~g} \mathrm{~kg}^{-1}$ of total nitrogen in the cultivated layer $(0-30 \mathrm{~cm})$.

The fields have been under dry arable cultivation for the last two decades, under a rotation including primarily durum wheat (Triticum durum Desf.) and annual forage crops, mainly crimson clover (Trifolium incarnatum, L.) as a pure stand or as a mixture with oats (Avena sativa L.) and common vetch (Vicia sativa L.). In the 20072008 and 2008-2009 growth seasons, the two sites were employed for a paired comparison of different agronomic management for biofuel crop productions, namely a winter crop, i.e. rapeseed (Brassica napa L.), in 2008 and a spring crop, i.e. sunflower (Heliantus annuus, L.), in 2009. One of the fields (IT-Ro3) was managed conventionally using mouldboard ploughing and disk harrowing, while the other (IT-Ro4) was managed as a no-tillage system. After 2009, the farm was converted into an organic agriculture regime and the no-tillage field, typically requiring chemical weeding, was then reverted to conventional tillage. Both fields were occupied by organically grown crimson clover (T. incarnatum) for seed production in the 2009-2010 growth season. In 2010-2011, the IT-Ro3 field was employed for (organic) durum wheat production, whereas the IT-Ro4 field was occupied by crimson clover employed as an annual forage crop, i.e. occasionally grazed by cattle. In the 2011-2012 growth season one of the fields (IT-Ro4) was managed as crimson clover for seed and straw production while the other (IT-Ro3) was occupied by a mixture of vetch and oats employed as a forage crop with occasional cattle grazing and final hay harvest in June.

\subsubsection{Renon (IT-Ren)}

The Renon-Selva Verde site $\left(46.58686^{\circ} \mathrm{N} ; 11.43369^{\circ}\right.$ E, elevation about 1,735 m.a.s.1.) is located in the municipality of Renon, at a distance of $12.2 \mathrm{~km}$ North-Northeast from the town of Bolzano. Eddy Covariance measurements started in the year 1997. The site is placed on a porphyric plateau; the soil is classified as Haplic Podsol following FAO (2008).

The site vegetation, a subalpine coniferous forest, is of natural origin and is used for wood production. As a result of the traditional harvesting method, which consists of irregular cuttings of 50-80 cubic meters, overall the forest is unevenly aged, but with homogenous groups. The largest group present in the area has been approximately growing since the year 1820, after the Napoleonic wars. The main forest species is spruce (Picea abies (L.) Karst., $85 \%$ in number) followed by cembran pine (Pinus cembra L., $12 \%$ ) and larch (Larix decidua Mill., $3 \%$ ). In the clearings, covering approximately $15 \%$ of the area, the dominant grass species is Deschampsia flexuosa L. The canopy is irregular, with a maximal height of $29 \mathrm{~m}$. The average LAI, measured by hemispherical photographs, is 5.1 (Montagnani et al. 2009). 
The climate is strongly influenced by elevation, with cool summers and moderately cold winters. During the last decade, the average temperature was $6.21{ }^{\circ} \mathrm{C}$ and the annual precipitation was $964.21 \mathrm{~mm}$ (Niu et al. 2011).

\subsubsection{San Rossore (IT-SRo)}

The study site is an even aged Pinus pinaster forest located $9 \mathrm{~km}$ west of Pisa (central Italy) and $800 \mathrm{~m}$ east of seashore inside the regional park of San RossoreMigliarino-Massaciuccoli, $\left(43.72786^{\circ} \mathrm{N} ; 10.28444^{\circ} \mathrm{E}\right.$, elevation 6 m.a.s.l.) The park extends for 24,000 ha about $30 \mathrm{~km}$ between Livorno and Viareggio along the Tyrrhenian coast with an estuarial morphology characterized by the presence of alluvial deposits and sandy dunes between the rivers Serchio and Arno. Pinus pinaster Aiton was introduced in 1771 in a strip of ca $10 \times 1 \mathrm{~km}$ behind the dunes in order to protect the economically important $P$. pinea $\mathrm{L}$. plantations more inland. Before human intervention, the $P$. pinaster area was covered by Mediterranean sclerophyllous forests and scrubs, a formation of Ligurian-Thyrrenian meso-Mediterranean holm oak forests (Quercus ilex L.) with Fraxinus ornus L., Ostrya carpinifolia Scop., Viburnum tinus L. The current $P$. pinaster forest established from seed after a big fire in 1944 and was never thinned systematically. A survey of the experimental plot in 2000 showed a tree density of 587 trees per ha (84\% P. pinaster, $12 \%$ P. pinea, $4 \%$ Q. ilex in the understorey), a basal area of $40 \mathrm{~m}^{2} \mathrm{ha}^{-1}$, an average canopy height of $18.7 \mathrm{~m}$, a LAI of 2.8 and a total aboveground and root biomass of 9.7 and $1.9 \mathrm{~kg} \mathrm{C} \mathrm{m}^{-2}$. Due to a very high ungulate density, there is no ground vegetation and only few shrubs like Phyllirea angustifolia L., Myrtus communis L., Erica arborea L. The soil in the pinewood is a regosol with a $93 \%$ sand texture extending down to $4 \mathrm{~m}$ depth. The top $10 \mathrm{~cm}$ of soil is characterized by $\mathrm{pH}\left(\mathrm{H}_{2} \mathrm{O}\right)$ of 6.5 and $\mathrm{C} / \mathrm{N}$ ratio of 25.2 ; rooting depth is limited by the water table varying between $100 \mathrm{~cm}$ in winter and $200 \mathrm{~cm}$ in summer. The climate of San Rossore is Mediterranean sub-humid, with an average annual rainfall of $876 \mathrm{~mm}$ and an annual temperature of $15.6{ }^{\circ} \mathrm{C}$. The wind regime is characterized by a land-sea breeze circulation with air flows from the west during the day and from the east during the night. A large scale dye back of $P$. pinaster took place in the 70 s due to the combined impact of marine aerosol and surfactants. Currently, the P. pinaster area is under a large scale attack of the maritime pine bast scale (Matsucoccus feytaudi) and is going to be transformed into a more natural land cover with dominant Q.ilex.

\subsubsection{Tolfa (IT-Tol)}

The Tolfa-Allumiere site $\left(42.18967^{\circ} \mathrm{N} ; 11.92155^{\circ} \mathrm{E}\right)$ is an evergreen broadleaf managed forest extending for about 6 ha, primarily characterized as Mediterranean Macchia and located in a small and isolated mountainous chain in Central Italy, close to the Tyrrhenian Sea. The elevation is 422 m.a.s.l. and the climate is 
essentially Mediterranean with a small increase in precipitation during autumn and spring, essentially driven by local meteorological circulation and updraft. The average annual precipitation is $650 \mathrm{~mm}$ while the average annual temperature is $15^{\circ} \mathrm{C}$. The site has been set up as part of a large scale manipulation experiment called LASMEX in the framework of EU-funded MIND project which aimed at studying the effect of increased or decreased precipitation intensities on Mediterranean ecosystems through rain exclusion or irrigation. This specific site is the reference site with unmodified precipitation regime. The vegetation is a coppice rotation primarily composed by Arbutus unedo L. (65\%) and Erica arborea L. (13\%) and secondarily by Fraxinus ornus L. and Quercus ilex L. The entire canopy grew up after fire events occurred on site in 1984. The soil is of volcanic origin and classified as Andosols, with an average depth of around $30 \mathrm{~cm}$ and acid $(\mathrm{pH}=4)$.

\subsubsection{Torgnon (IT-Tor)}

The site, active since June 2008, is an old grazed pasture abandoned in late 1990s in the northwestern Italian Alps. It is located a few kilometers away from the village of Torgnon in the Aosta Valley region at an elevation of 2,160 m.a.s.1. $\left(45.84444^{\circ} \mathrm{N} ; 7.57806^{\circ} \mathrm{E}\right)$.

The dominant vegetation is composed by Nardus stricta L., $35 \%$, Festuca nigrescens All. $11 \%$, Arnica montana L. $8 \%$, Carex sempervirens Vill. $5 \%$, Geum montanum L. $5 \%$, Anthoxanthum alpinum L.L. $4 \%$, Potentilla aurea L. $4 \%$, Trifolium alpinum L. $4 \%$. Considering canopy properties, maximum seasonal LAI is about 2.9 and average canopy height is $18 \mathrm{~cm}$. The terrain slopes gently $\left(4^{\circ}\right)$ and the soil is classified as Cambisol (WRB classification), with the following characteristics in the $0-20 \mathrm{~cm}$ horizon: organic $\mathrm{C}=2.8 \mathrm{~kg} \mathrm{C} \mathrm{m}^{-2}$ and total $\mathrm{N}=0.22 \mathrm{~kg} \mathrm{~N} \mathrm{~m}^{-2}$.

The site is characterized by an intra-alpine semi-continental climate, with strong seasonality, the average annual temperature is of $3.1{ }^{\circ} \mathrm{C}$ and the average annual precipitation is of about $880 \mathrm{~mm}$. On average, from the end of October to late May, the site is covered by a thick snow mantle $(90-120 \mathrm{~cm})$ which limits the growing season length to four-five months. Growing season cumulative precipitation can show huge variations (from 160 to $630 \mathrm{~mm}$ ) and the average daily air temperature varies between 4 and $13{ }^{\circ} \mathrm{C}$.

\subsubsection{Valle dell'Adige (IT-VdA)}

The Valle dell'Adige site is located in a vineyard in the Valle dell'Adige $\left(46.19678^{\circ} \mathrm{N} ; 11.11354^{\circ} \mathrm{E}\right.$; Mezzolombardo) at an altitude of 206 m.a.s.l. The average annual air temperature is $11.8{ }^{\circ} \mathrm{C}$ while the average annual precipitation is $822 \mathrm{~mm}$. The soil was classified as a Gleyic/Haplic Fluvisol (FAO 2008) with the following characteristics in the $0-30 \mathrm{~cm}$ horizon: sand $42 \%$, silt $47 \%$, clay 
$11 \%$, total soil organic content $(\mathrm{SOC})=5.85 \mathrm{~kg} \mathrm{C} \mathrm{m}^{-2}$, total $\mathrm{N}=0.66 \mathrm{~kg} \mathrm{~N} \mathrm{~m}^{-2}$, bulk density $0.96 \mathrm{~g}$ soil $\mathrm{cm}^{-3}$. The vineyard covers an area of approximately $2.5 \times 1 \mathrm{~km}$ cultivated with Vitis vinifera L. cultivar "Teroldego rotaliano", and includes small patches of apple trees. The vegetation is about $2.0 \mathrm{~m}$ tall with more than $50 \%$ ground shading. Mass and energy fluxes have been continuously measured since 2008 at the site with an Eddy Covariance system mounted at $7 \mathrm{~m}$ height.

The growing season starts in the middle of March and lasts until the end of September with maximum carbon dioxide uptake at the end of April (for high radiation and water availability) and in July. During the winter season (from October to March) the vineyard acted as a carbon source.

\subsubsection{Vigevano (IT-Vig)}

The experimental site is located near the town of Vigevano $\left(45.29591^{\circ} \mathrm{N} ; 8.87554^{\circ}\right.$ E, 117 m.a.s.1.) in the Lombardy Region, in the Province of Pavia and it consists of a poplar short rotation coppice (SRC) (P. generosa $\times$ P. nigra clone Pegaso) of about 80 ha. The traditional agricultural land use of the area is a corn-rice rotation transformed into SRC in March 2004 by planting one year old seedlings in a double row design with a spacing of $2.8 \times 0.75 \times 0.45 \mathrm{~m}$ corresponding to a density of 12.500 plants $\mathrm{ha}^{-1}$. Before planting, soil was ploughed and disk-harrowed. After planting, a pre-emergent herbicide was applied at $2 \mathrm{~kg} \mathrm{ha}^{-1}$ with a pull type sprayer. In the following years weed control was done mechanically four times in spring and summer with a rototiller. From May to September the experimental field was irrigated with a volume of water of $1,500 \mathrm{~m}^{-3} \mathrm{ha}^{-1}$. Poplar shoots were harvested and chipped annually during winter with a special harvester and used in a nearby incinerator for energy production. No fertilizer was applied during the first three years of SRC cultivation. The soil is from fluvial sediments and has a sandy loam texture (53\% sand, $30 \%$ silt and $17 \%$ clay), bulk density is $1.21 \mathrm{~g} \mathrm{~cm}^{-3}$, $\mathrm{pH}\left(\mathrm{H}_{2} \mathrm{O}\right)$ is 6.5 in the uppermost $32 \mathrm{~cm}$. The net primary production (NPP) as measured as sum of stem+branch, coarse roots, fine roots, stump, leaf litter and fine root litter increased in 2004-2006 from 0.69 to 1.05 to $1.3 \mathrm{~kg} \mathrm{C} \mathrm{m}^{-2}$ year $^{-1}$. The height of the canopy reached $4.5 \mathrm{~m}$ in one year, the LAI peaked in JulyAugust at 4.2. The average specific leaf area (SLA) of poplar leaves was 296.56 $( \pm 60.09) \mathrm{cm}^{2} \mathrm{~g} \mathrm{DM}^{-1}$. The climate of the site is classified as Humid SubtropicalMid Mild Latitude (Cfa)—Koppen Climate Classification, with an average annual rainfall of around $1,000 \mathrm{~mm}$ and an average temperature of about $12.5^{\circ} \mathrm{C}$.

\subsection{Example of Measurements}

The NEE measurements using the Eddy Covariance technique are typically half hourly average values expressed in $\mu \mathrm{mol} \mathrm{CO}_{2} \mathrm{~m}^{-2} \mathrm{~s}^{-1}$. The data can be clearly used to calculate daily to annual sums and budgets which are then expressed in 


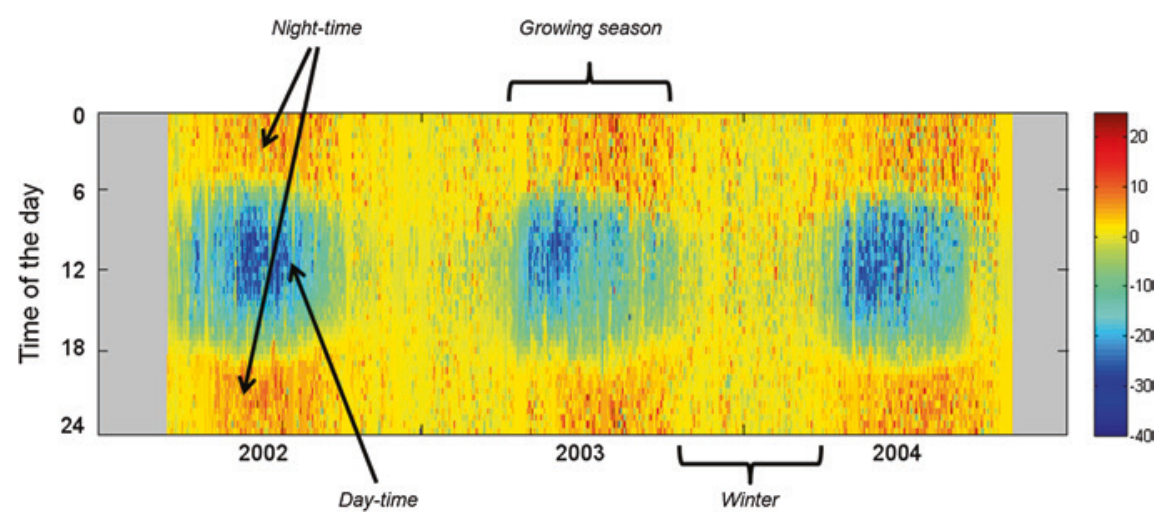

Fig. 2.2 Example of fingerprint plot to visualize Eddy Covariance time series. The colors are instantaneous (half hour) $\mathrm{CO}_{2}$ fluxes in $\mu \mathrm{mol} \mathrm{CO}_{2} \mathrm{~m}^{-2} \mathrm{~s}^{-1}$ (site IT-PT1). It is possible to see clearly the seasonal dynamic with emissions of $\mathrm{CO}_{2}$ during winter when only respiration is present and the diurnal cycle with $\mathrm{CO}_{2}$ assimilation in the daytime. The minor $\mathrm{CO}_{2}$ uptake in the summer of 2003 is to be noted, as a consequence of the European heat wave (Ciais et al. 2005)

general as $\mathrm{g} \mathrm{C} \mathrm{m}^{-2} \mathrm{day}^{-1}$. By convention, negative values are fluxes going from the atmosphere to the ecosystem (carbon sink).

One of the best ways in order to have a graphical overview of the measurements is the "fingerprint" plot (Fig. 2.2): it is an image where on the X axis there are the days, on the $\mathrm{Y}$ axis the hours and the color indicate the flux magnitude and sign. Using this type of plot it is possible to easily follow and analyze the diurnal, seasonal and inter annual patterns and identify anomalies.

The Fig. 2.3 shows the comparison of two cropland sites (IT-BCi cultivated with maize all the years and IT-Be2 cultivated with alfalfa in 2007-2009 and maize in 2010) and it is possible to see the effect of the management options: tillage before the carbon uptake period (CUP) in IT-BCi, the four harvest in 20072009 in IT-Be2 and the difference in the magnitude of the uptake, with the maize reaching higher values (C4 photosynthesis) in IT-BCi and also in IT-Be2 in 2010 (see Sect. 2.2.2). In the same figure a grassland site with a long time series of data is also reported (IT-MBo) and it is possible to identify the differences in the seasonal cycle with a winter basically without activities because of the snow and cold temperature.

Another interesting example is given by the comparison of the two oak coppice forests in central Italy (Fig. 2.4). The two sites are in two compartments with different ages with IT-Ro1 monitoring a forest just after the harvesting occurred in 2000 and IT-Ro2 in an older forest now ready to be harvested. It is interesting to note that the fluxes are higher in the mature forest but also the young stand recovered quite rapidly a good photosynthesis capacity. In addition in both the stands it is possible to see the effect of the heat-wave in 2003 (Ciais et al. 2005) with a strong reduction of the carbon assimilation in summer and a similar anomaly also in 2008. 


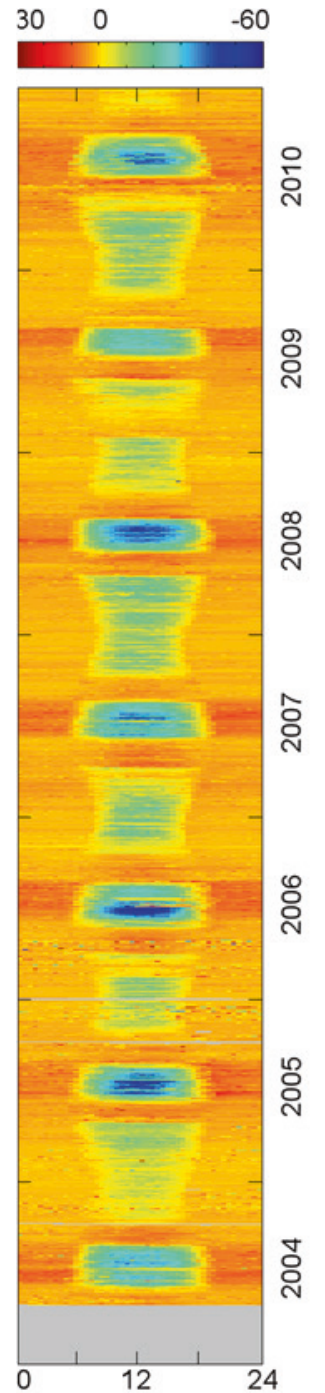

IT-BCi

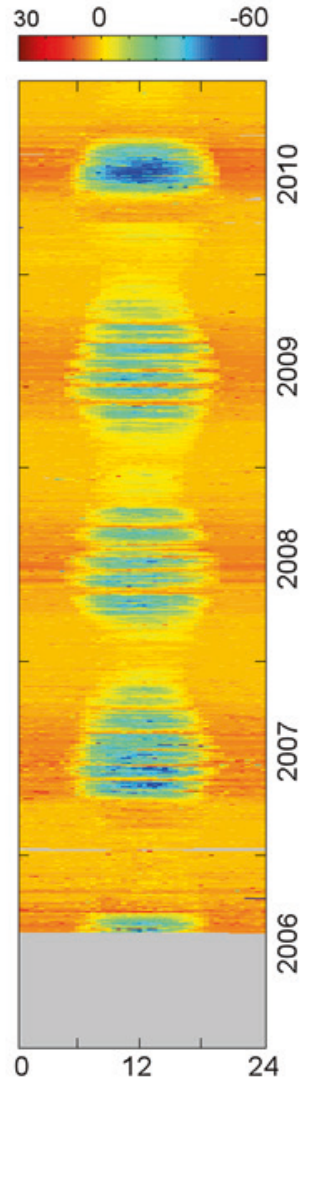

IT-Be2

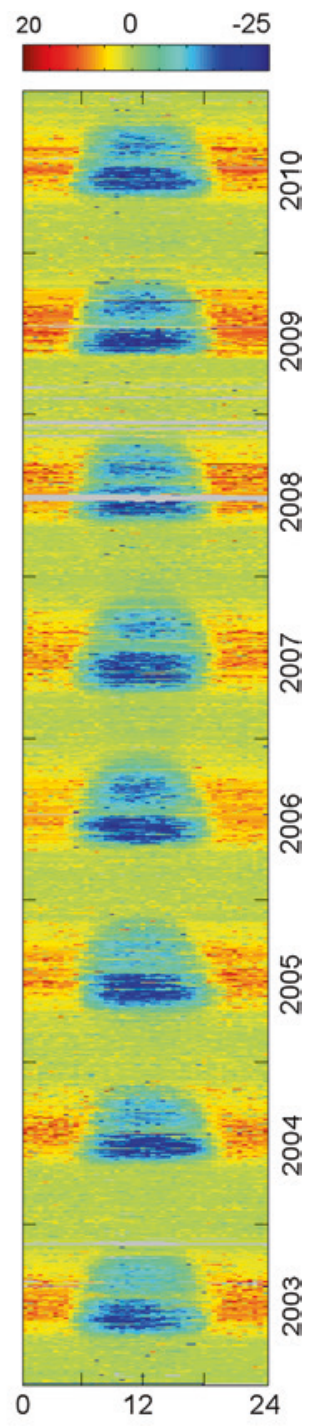

IT-MBo

Fig. 2.3 Comparison of two cropland sites: IT-BCi cultivated with maize all the years and IT-Be2 cultivated with alfalfa in 2007-2009 and maize in 2010. The colors are instantaneous (half hour) $\mathrm{CO}_{2}$ fluxes in umol $\mathrm{CO}_{2} \mathrm{~m}^{-2} \mathrm{~s}^{-1}$. It is possible to note the different magnitude of the uptake between the two species and the effect of the management practices. The third site (IT-MBo) is a grassland site and it is interesting to note the low fluxes during winter and the growing season characterized by two assimilation picks 
Fig. 2.4 Comparison of the two forest sites in Roccarespampani: IT-Ro1 and IT-Ro2 are in two different compartments with different stand ages but it is possible to identify common patterns (2003 and 2008) and seasonal dynamics. In addition to this, it is possible to see in IT-Ro1 the recovery of the forest after the harvesting in 2000 . The colors are instantaneous (half hour) $\mathrm{CO}_{2}$ fluxes in $\mu \mathrm{mol}$ $\mathrm{CO}_{2} \mathrm{~m}^{-2} \mathrm{~s}^{-1}$
IT-Ro1

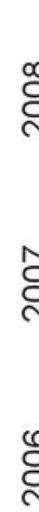

IT-Ro2

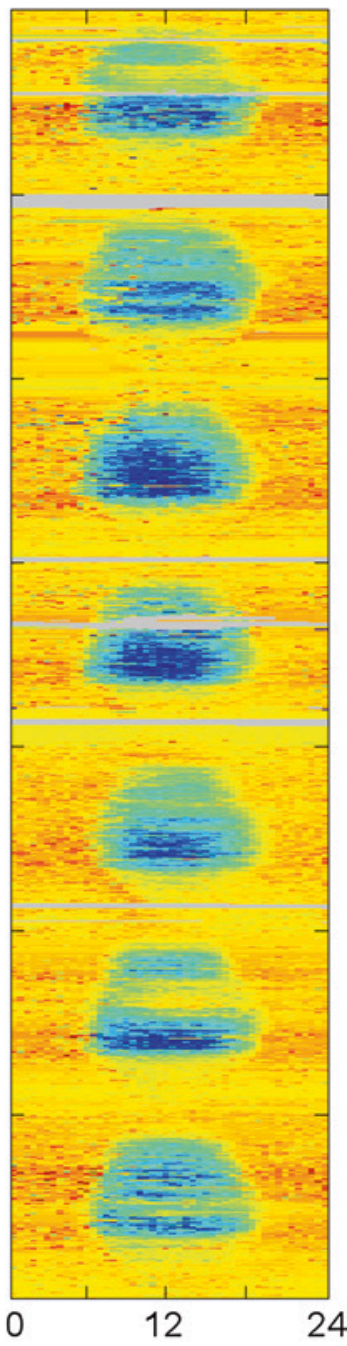

20

0 


\subsection{Analysis of Climate-Carbon NEE Interactions}

The long time series of Carbon NEE, meteorological variables and ecosystem status characteristics measured by the Italian network of Eddy Covariance sites can be used to analyze the interactions between climate and ecosystem processes. Understanding the driver factors controlling the capacity of terrestrial ecosystems to store carbon is extremely important in the context of climate variability and climate changes processes.

Carbon fluxes measured at the Italian sites have been used to analyze the role of the main meteorological variables and length of the CUP in the annual NEE across sites and the inter annual variability.

\subsubsection{Quality Criteria and Data Selection}

The annual NEE has been calculated as the median of the four cumulative values of daily NEE time series that have been routinely produced in the Carbo Italy database using different processing approaches (gap filling and storage correction). Uncertainty of annual NEE ( $\left.\mathrm{NEE}_{\max -\min }\right)$ has been instead estimated as the difference between the maximum and minimum cumulative values of the four daily NEE time series.

Two quality criteria have been used to select site years to be included in the analysis. The first quality check excludes site years with less than 330 days of data. The second criteria is based on the quality flags of daily NEE time series (defined in Reichstein et al. 2005) that indicate the percentage of high original measurements for each daily NEE value or high quality gap filled data: in particular a site year is discarded if any of the four NEE versions has a within year percentage of low quality days (daily quality flag < 0.85 ) higher than $25 \%$.

The application of these quality criteria resulted in a dataset for analysis which includes 22 cropland (CRO) site years, 26 deciduous broadleaf forest (DBF), 18 evergreen broadleaf forest (EBF), 27 evergreen needle leaf forest (ENF) and 14 grassland (GRA).

\subsubsection{Relationships Between Carbon Uptake Period Duration and Annual Net Ecosystem Exchange}

The analysis of the relationship between annual cumulated NEE and the duration of the CUP has been conducted aggregating site years according to PFT. CUP for all site years has been computed as the number of days with daily NEE $<-1 \mathrm{~g} \mathrm{C} \mathrm{m}^{-2} \mathrm{~d}^{-1}$. A linear regression analysis at PFT level has been conducted in order to evaluate annual NEE sensitivity to CUP. Data have been weighted according to the uncertainty estimates (NEE $\mathrm{max}_{\min }$ ) defined as described in Sect. 2.4.1.

Results of the linear regression analysis between annual NEE and CUP are reported in Fig. 2.5. Higher $\mathrm{R}^{2}$ values are obtained for EBF, ENF and GRA as presented in Fig. 2.6. DBF is the PFT with the lowest $\mathrm{R}^{2}$ value probably because 
(a)

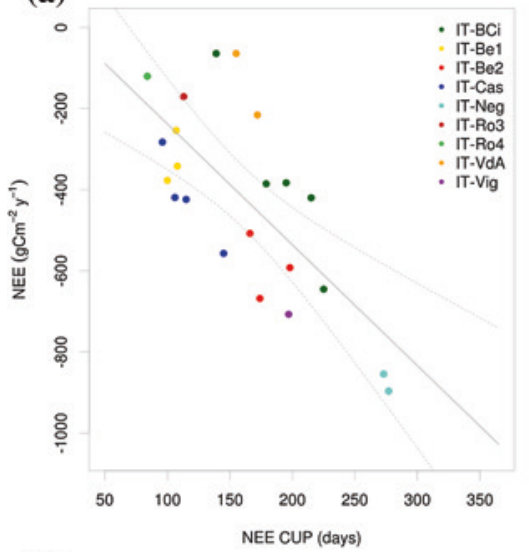

(c)

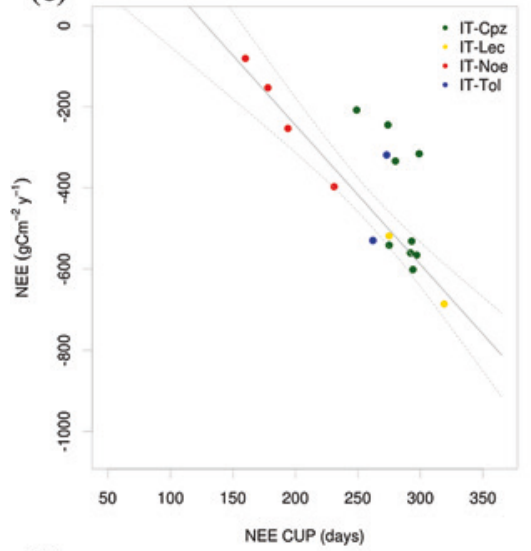

(e)

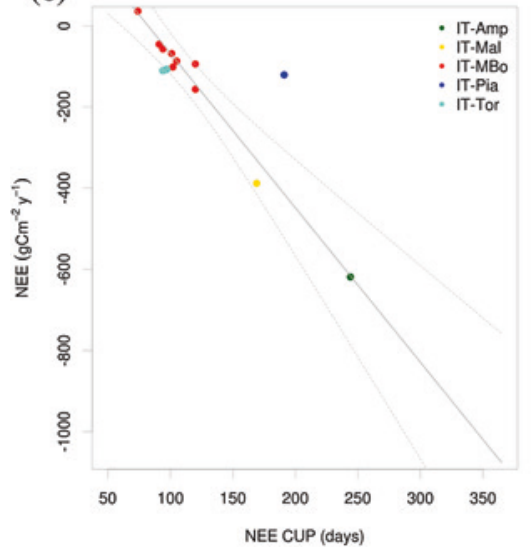

(b)

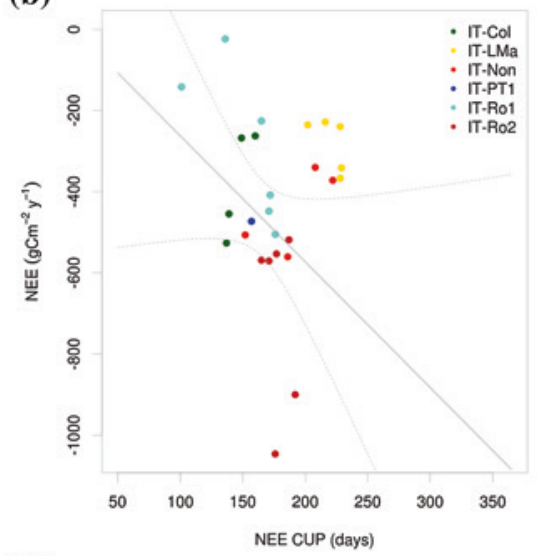

(d)

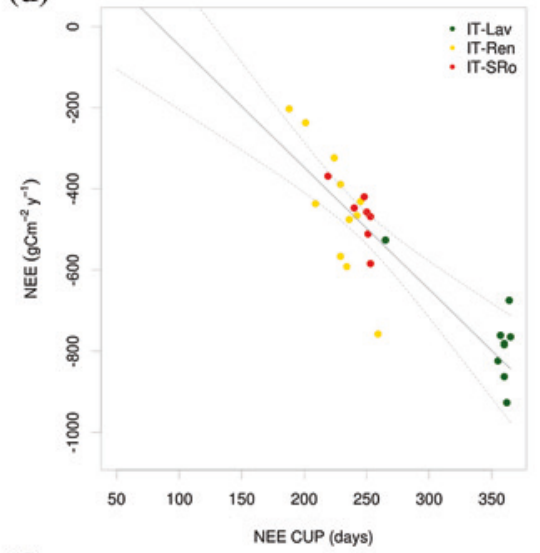

(f)

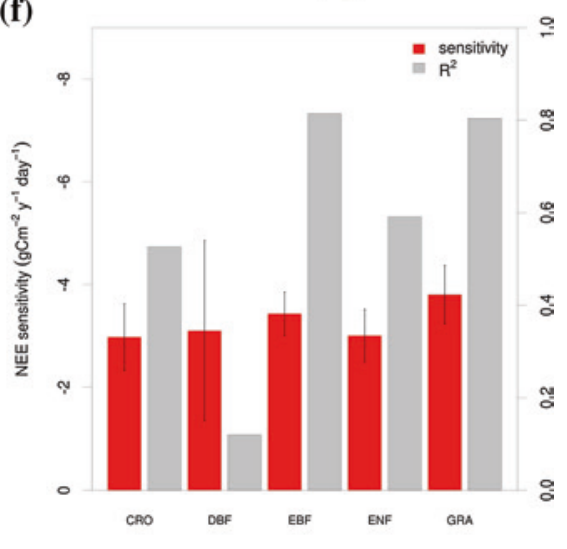

Fig. 2.5 Linear regression analysis between NEE annual values and CUP for each PFT. Panel $\mathbf{f}$ presents the sensitivity (red bars with s.e.) and $\mathrm{R}^{2}$ (grey bars) of the relation between NEE and CUP for each PFT 

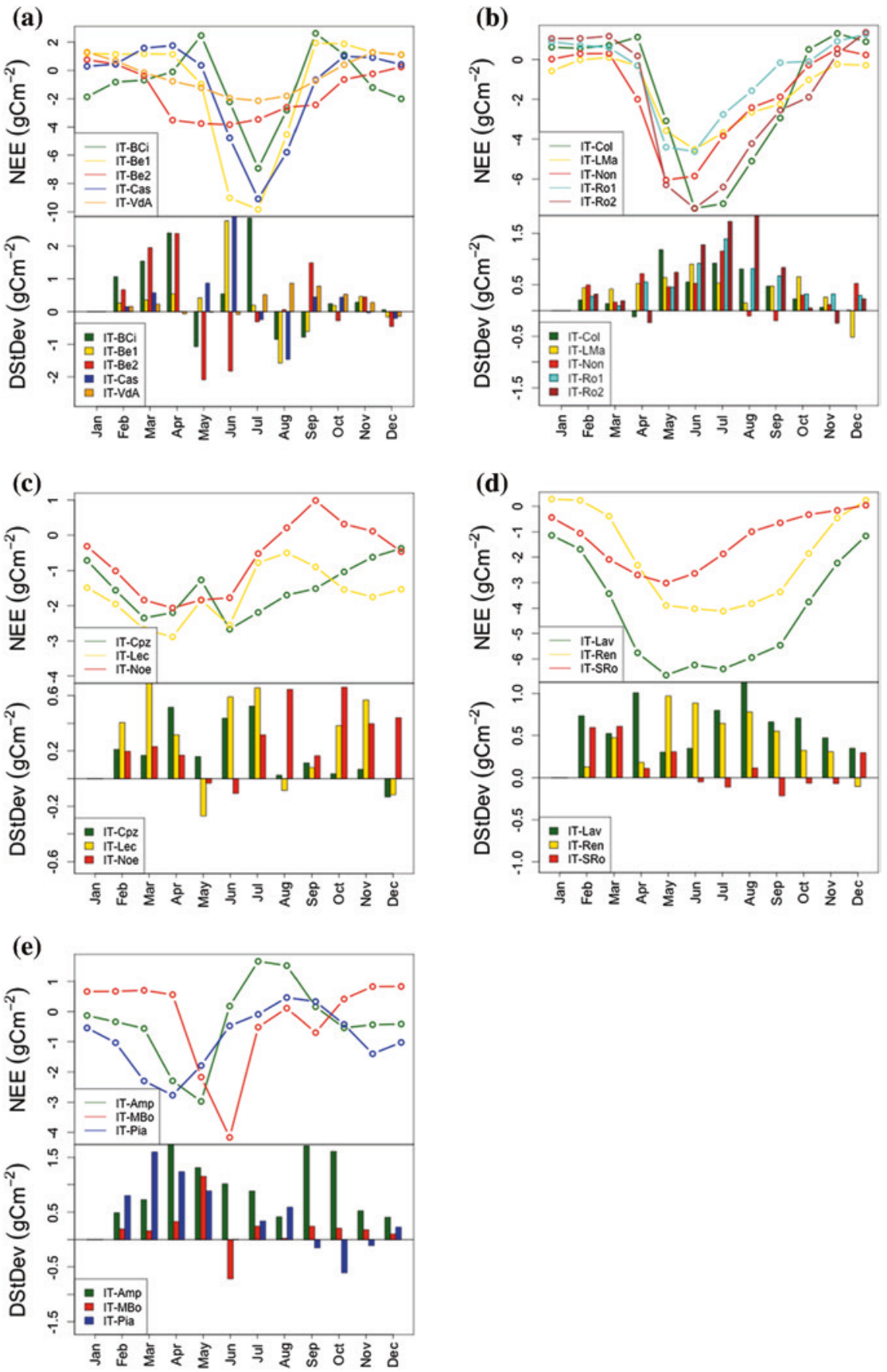

Fig. 2.6 Time series of average monthly NEE for the period reported in the database for each site (upper panel); barplot of DStDev over the observation period (lower panel). Different bars represent different sites. Different plots represents different PFTs 
of the large variability of ecosystems traits of sites that are included in this PFT; in fact the DBF sites in the networks are highly heterogeneous, with mature forests (IT-Col), coppices with different ages (IT-Ro1 and IT-Ro2) and a poplar plantation (IT-PT1). PFT annual NEE sensitivity to CUP variations range between $-2.97 \pm 0.64$ for CRO and $-3.80 \pm 0.56 \mathrm{C} \mathrm{m}^{-2} \mathrm{yr}^{-1} \mathrm{day}^{-1}$ for GRA.

Within some PFTs, sites with particular behaviors emerged (e.g. IT-Cpz for EBF and IT-Pia, included in this analysis in the grassland PFT) probably because of the effect of some site properties (in IT-Cpz for example there is the effect of the water table depth) or ecological parameters (e.g. LAI, fertility, ...) on the relation between annual NEE and CUP. These effects generally resulted in a similar NEE sensitivity to CUP variations but with different absolute values.

Moreover CRO and GRA, PFTs where management can play an important role, showed quite good relationship between NEE and CUP and sensitivity values similar to those obtained in the other PFTs (Fig. 2.5a, e).

\subsubsection{Analysis of the Relationship Between Annual NEE and Climate Variables}

The analysis of the relationship between annual cumulated NEE and climate variables has been conducted by aggregating site years according to the PTF. The analysis has been conducted in three different steps:

1. As a first attempt, a correlation analysis between annual NEE and average annual climate variables has been conducted. As climate variables temperature, precipitation, radiation and vapor pressure deficit (VPD) have been used.

2. In a second step, the stepwise regression has been used for the selection of the best predictive variables of annual NEE. The predictive variables tested were meteorological variables (T, Prec, VPD, Rg), LAI- and phenological indicators (i.e. CUP). A stepwise approach based on the Akaike's Information Criterion (AIC) for model selection has been implemented. The AIC is a measure of the trade-off between the goodness-of-fit (model explanatory power) and model complexity (number of parameters). Therefore, the stepwise based on AIC is a multiple regression method for variable selection which accounts on one hand for the model explanatory power, and on the other for the increasing complexity of the model when additional variables are tested in the multiple regression model (Venables and Ripley 2002; Yamashita et al. 2007). The stepwise AIC was preferred to other stepwise methods for variable selection since it can be applied to non-normally distributed data (Yamashita et al. 2007). The data have been weighted according to the uncertainty estimates $\left(\mathrm{NEE}_{\max -\mathrm{min}}\right)$, defined as described in Sect. 2.4.1 The outcome of the stepwise AIC is a multiple linear model including the best set of predictive variables explaining the variability of annual NEE. Therefore, by applying stepwise AIC as explained above, the drivers explaining the variability of NEE for each PFT have been identified while the coefficients estimated for each selected variable represent the sensitivity of NEE to variations of each predictor. 
3. In the third analysis, the inter-annual variability has been analyzed defining for each site with more than 3 years of data, the phenological period that mostly contribute to annual NEE variability. Following Marcolla et al. (2011), for each site-year the time series of cumulative monthly NEE and its standard deviation have been computed. According to Marcolla et al. (2011), variations of standard deviation from one month to the preceeding one (DStDev) quantifies the contribution of each month to the observed interannual variability (IAV). The analysis has been conducted also at weekly time scale with comparable results (data not shown). Resulting DStDev positive values means that the specific period contributes to the increase of the between year flux variability. Positive peaks of DStDev mean that climatic conditions in the period in which the peak occurs largely influence the inter annual variability. Periods with negative values of DStDev tend instead to mitigate the inter annual variability of NEE. Once the critical period for each PFT has been identified, the stepwise AIC regression between annual NEE and different predictors has been re-computed. Not only have the average annual values of climate predictors been tested, but also subannual variable aggregation (i.e. average temperature in spring and summer; cumulative precipitation in summer etc.). For each PFT the main driver controlling spatial and year-to-year variation in NEE has then been identified.

The results of the pair wise correlation analysis between annual NEE and climate variables conducted for each PFT are reported in Table 2.1. The results show that average annual climatic variables cannot explain the variability of NEE except for the EBF, for which a statistically significant correlation $(p<0.05)$ with Ta, Ts and $\mathrm{Rg}$ have been found and for ENF, for which a correlation between NEE and Soil Water Content (SWC) is observed.

In Table 2.2 the results of the stepwise AIC regression between cumulative NEE and annual climatic predictors are reported. Even including multiple climate predictors, a statistical significant correlation with NEE is observed only for the evergreen PFTs (EBF and ENF).

By including as predictors the CUP and LAI, an important improvement of the $\mathrm{R}^{2} \mathrm{adj}$ has been observed, highlighting the importance of structural site

Table 2.1 Pairwise correlation ( $r$ ) between annual NEE cumulated and annual average of meteorological variables

\begin{tabular}{l|l|l|l|l|l|l}
\hline & $\mathrm{Rg}$ & $\mathrm{Ta}$ & $\mathrm{Ts}$ & VPD & Precip & SWC \\
\hline ENF & 0.01 & 0.00 & 0.00 & 0.00 & 0.00 & 0.44 \\
\hline DBF & 0.02 & 0.00 & 0.01 & 0.01 & 0.03 & 0.02 \\
\hline EBF & 0.49 & 0.70 & 0.58 & 0.01 & 0.08 & 0.04 \\
\hline CRO & 0.03 & 0.00 & 0.03 & 0.09 & 0.04 & 0.02 \\
\hline GRA & 0.26 & 0.00 & 0.02 & 0.01 & 0.00 & 0.21 \\
\hline
\end{tabular}

Bold numbers represent statistical significant correlations $(p<0.01)$. Rg Shortwave Incoming Radiation, $T a$ Air Temperature, $T s$ Soil Temperature, VPD Vapur Pressure Deficit, Precip Precipitation, SWC Soil Water Content 
Table 2.2 Results of model selection conducted with the stepwise AIC method using as predictor annual averages of meteorological variables

\begin{tabular}{l|l|l|l|l|l|l|l}
\hline PFT & Ta & Precip & Intercept & $\mathrm{R}^{2}$ adj & $P$ & AIC & $\mathrm{N}$ \\
\hline ENF & $13.08(8.52)$ & $-0.33(0.15)$ & -456.3 & 0.36 & $<0.001$ & 108.6 & 12 \\
\hline DBF & & & & & NS & NS & 14 \\
\hline EBF & $95.04(25.02)$ & $-0.16(0.10)$ & $-1,783.59$ & 0.66 & $<0.01$ & 88.99 & 12 \\
\hline CRO & & & & & NS & NS & 15 \\
\hline GRA & & & & & NS & NS & 14 \\
\hline
\end{tabular}

Coefficients, their standard errors and the statistics of the best model selected are reported. $\mathrm{Ta}$ Air Temperature, Precip Precipitation, AIK Akaike's Information Criterion, NS not significant

Table 2.3 Results of model selection conducted with the stepwise AIC method using as predictor annual averages of meteorological variables, LAI and CUP

\begin{tabular}{|c|c|c|c|c|c|c|c|c|c|c|}
\hline PFT & $\mathrm{Rg}$ & $\mathrm{Ta}$ & Precip & LAI & CUP & Intercept & $\mathrm{R}^{2} \mathrm{adj}$ & $P$ & AIC & $\mathrm{N}$ \\
\hline ENF & & $\begin{array}{l}-17.32 \\
(10.77)\end{array}$ & & \begin{tabular}{|l|}
-116.23 \\
$(31.06)$
\end{tabular} & & 276.21 & 0.64 & $<0.01$ & 101.8 & 12 \\
\hline DBF & $\begin{array}{l}-79.48 \\
(40.64)\end{array}$ & & & $\begin{array}{l}-52.76 \\
(41.37)\end{array}$ & $\begin{array}{l}-5.39 \\
(1.98)\end{array}$ & $1,732.9$ & 0.32 & $<0.05$ & 203.4 & 14 \\
\hline EBF & & $\begin{array}{l}95.04 \\
(25.02)\end{array}$ & $\begin{array}{l}-0.16 \\
(0.10)\end{array}$ & & & $-1,783.6$ & 0.66 & $<0.01$ & 88.99 & 12 \\
\hline $\mathrm{CRO}$ & & & & & & & NS & NS & NS & 15 \\
\hline GRA & $\begin{array}{l}-28.53 \\
(16.67)\end{array}$ & $\begin{array}{l}20.19 \\
(8.85)\end{array}$ & & $\begin{array}{l}-64.51 \\
(30.51)\end{array}$ & $\begin{array}{l}-4.25 \\
(0.37)\end{array}$ & 824.96 & 0.95 & $<0.001$ & 103.12 & 14 \\
\hline
\end{tabular}

Coefficients, their standard errors and the statistics of the best model selected are reported. Rg Shortwave Incoming Radiation, Ta Air Temperature, Precip Precipitation, AIK Akaike's Information Criterion, NS not significant

characteristics and phenology in determining the spatial and temporal variability of annual NEE (Table 2.3).

The results of the DStdev computed for each site and grouped for PFT are reported in Fig. 2.6. The time series of DStDev highlights the period that mostly contribute to the inter annual variability of NEE at each site (hereafter referred as the critical period).

As an example, the DStDev computed for IT-MBo site (Fig. 2.5e) shows an abrupt increase in DStDev at the onset of the growing season indicating that this period has an important role in the IAV definition. Marcolla et al. 2011 concluded that climatic conditions and snow cover in late spring largely influence the interannual variability of NEE of this alpine grassland, and that the first half of the growing season at IT-MBo mitigates the IAV thanks to the negative correlation $(\mathrm{R}=-0.77$ ) between the timing of snowmelt and the rate of carbon uptake at the beginning of the growing season. A second peak of DStDev due to the variable timing of the meadow cut has been observed, emphasizing the important role of management in controlling the inter annual variability.

The results show that for almost all the PFTs the critical period for the IAV occurs during the spring transient of NEE, when carbon uptake begins after winter, and in some water limited sites at the end of the growing season in late summer. 
Table 2.4 Results of model selection conducted with the stepwise AIC method using as predictor annual and sub annual averages of meteorological variables

\begin{tabular}{l|l|l|l|l|l|l|l}
\hline PFT & Predictors selected & $\mathrm{R}^{2}$ adj & $P$ & AIC & $\begin{array}{l}\text { AIC (ann. } \\
\text { climate) }\end{array}$ & $\begin{array}{l}\text { AIC (ann. } \\
\text { climate + LAI } \\
\text { and CUP) }\end{array}$ & $\mathrm{N}$ \\
\hline ENF & $\begin{array}{l}\text { CUP, LAI, Rg, } \\
\text { PREC_CUP, } \\
\text { TA_JJA, TA_MAM }\end{array}$ & 0.98 & $<0.001$ & 59.73 & 108.6 & 101.8 & 12 \\
\hline DBF & $\begin{array}{l}\text { CUP, Rg, } \\
\text { LAI,TA_JJA, } \\
\text { TA_MAM, } \\
\text { PREC_JJA }\end{array}$ & 0.47 & $<0.05$ & 200.23 & NS & 203.4 & 14 \\
\hline EBF & $\begin{array}{l}\text { TA_MAM, Rg, } \\
\text { PREC_CUP }\end{array}$ & 0.91 & $<0.001$ & 88.65 & 88.99 & 88.99 & 12 \\
\hline CRO & $\begin{array}{l}\text { VPD_MAM, } \\
\text { PREC_CUP }\end{array}$ & 0.44 & $<0.05$ & 147.85 & NS & NS & 15 \\
\hline GRA & $\begin{array}{l}\text { CUP, TA_MAM, } \\
\text { Rg,LAI }\end{array}$ & 0.95 & $<0.001$ & 101.71 & NS & 103.12 & 14 \\
\hline
\end{tabular}

PREC Precipitation, TA Air Temperature, $R g$ Incoming Shortwave Radiation, VPD Vapor Pressure Deficit, LAI and CUP. The averages have been calculated for groups of months (MAM March-April-May, JJA June-July-August) of for the whole Carbon Uptake Period (e.g. for PREC_CUP). For each PTF the list of selected predictors are reported. In the column 'predictors selected' bold variables indicate a positive correlation with NEE positive coefficient) while variables in italics indicate negative correlation (negative coefficient). The AIC for the stepwise analysis with annual meteorological variable (Table 2.1) and meteorological variable, LAI and CUP (Table 2.2) are also reported for comparison. AIK Akaike's Information Criterion

This has been observed for all the PFTs even if for EBF the signal is weaker and more variable. For CRO the management might be an important confounding factor hampering the identification of the critical period.

Finally, the results of the stepwise AIC analysis is reported in Table 2.4 including as predictor also sub-annual aggregation of climate drivers. These results emphasize that studies focused on the relationship between climate and NEE should investigate the climate variability in particular periods rather than the average climate (Le Maire et al. 2010).

The results showed that for almost all the PFT, the average spring temperature (March, April and May, TA_MAM) is selected as predictor of year-to-year and spatial variations of annual NEE. Cumulative precipitation in summer (June, July and August) or during the entire CUP (PREC_JJA or PREC_CUP) are also selected as predictor of the variability in many PFTs, thus, indicating the water control of NEE in many ecosystems and sites selected.

Moreover, LAI and CUP are also often selected as additional predictors except for EBF and CRO indicating a strong control of LAI, explaining the spatial variability (i.e. across sites) of annual NEE, and phenology, which is one of the main factors controlling the temporal variability of NEE at site level (e.g. Marcolla et al. 2011).

Among the different PFTs, EBF shows the strongest climatic control of the inter annual and spatial variability of NEE. In particular, the variables selected by 
the stepwise are springtime temperature, precipitation during CUP and radiation. The strong control of climate on EBF has been already reported in a study which showed the effects of hydrological and climatic drivers on a Mediterranean oak forest (Delpierre et al. 2012).

To summarize, the analysis of the relationship between annual NEE and CUP showed that Italian sites sensitivity to CUP variation ranges from $-2.97 \pm 0.64$ to $-3.80 \pm 0.56 \mathrm{~g} \mathrm{C} \mathrm{m}^{-2} \mathrm{yr}^{-1} \mathrm{day}^{-1}$. EBF and GRA are the PFT with the higher portion of inter annual and spatial NEE variability explained by CUP.

Considering the relationship between annual NEE and climate variable, this analysis showed that studies focusing on the relationship between climate and inter annual variations of NEE should concentrate on the variability of climate variables in particular periods of the seasons rather than on the average climate.

\subsection{Conclusions}

The Eddy Covariance network of Italy provided a great opportunity for a better understanding of the carbon cycle and interaction between ecosystems and atmosphere. In addition, beside the unique collection of measurements that are today available to the benefit of the global scientific community, it has been possible to analyse the relations between NEE and main environmental factors, highlighting the importance of the growing season length and the role of specific climatic variables (mainly temperature and precipitation) in particular periods.

Although the CarboItaly project offering the opportunity to build-up the Italian network has now ended, the teams involved are still trying to do their best in order to continue the measurements collection in the belief that only a long term monitoring activity can provide the basis for an in-depth analysis of how ecosystems will react to climate changes and what their role can be. The importance of these measurements is also confirmed by the construction of the ESFRI (European Strategy Forum on Research Infrastructures) infrastructure ICOS-Integrated Carbon Observing System (www.icos-ri.eu) that will maintain Eddy Covariance sites running across Europe for the next 20 years.

\subsection{The Big Effort of Maintaining the Network and Acknowledgments}

The maintenance of a network of Eddy Covariance sites like the one described in this chapter has an enormous cost mainly in terms of personnel to be dedicated to the different sites and database. Equipments selection and setup, sensors calibration and control, data collection, data screening, fluxes calculation, database management and additional QA/QC are all fundamental steps that require high level of expertise and preparation. The CarboItaly project provided the broad scientific 
community with a unique dataset coming from one of the most dense networks of Eddy Covariance sites in Europe; this has been possible thanks to the financial support of the CarboItaly FISR project and a number of European research projects, in particular EuroFlux, CarboEuroFlux, CarboEuropeIP and GHG-Europe. However, all this could not have been possible without the professional and qualified contribution of a number of scientists, $\mathrm{PhD}$ students and technicians who devoted large portions of their time to the collection of these measurements, often in difficult meteorological conditions, and then decided to share their data with colleagues around the World in name of the scientific progress. For this reason the main credits of the co-authors of the chapter goes to them, that we want to namely list also to give an indication of the effort needed to collect these measurements: Michael Andersson, Angelo Arca, Nicola Arriga, Narciso Avanzo, Silvia Baronti, Giovanni Callegari, Mario Cammarano, Mauro Cavagna, Alessandro Ciaccia, Roberto Colombo, Ettore D’Andrea, Matteo Danelon, Bruno De Cinti, Giuseppe de Simon, Filippo Di Gennaro, Floriano Di Nardo, Sabina Dore, Dieter Droste, Marlene Duerr, Chiara Ferrè, Alessandro Fiora, Antonio Forgione, Gerardo Fratini, Olga Gavrichkova, Ignacio Goded Ballarin, Gabriele Guidolotti, Francesco Iovino, Mario Lanini, Ramona Magno, Giovanni Manca, Barbara Marcolla, Matteo Mari, Caterina Marino, Serena Marras, Alessandro Matese, Francesco Mazzenga, Franco Meggio, Ana Meijide, Michele Meroni, Stefano Minerbi, Umberto Morra di Cella, Marianna Nardino, Antonia Oriani, Emiliano Pegoraro, Fabio Pieruccetti, Jacopo Primicerio,

Nicola Ricca, Emiliano Rosato, Francesco Sabatini, Antonino Sammartano, Giuseppe Santarelli, Giuseppe Scarascia Mugnozza, Andrea Scartazza, Uwe Schwarz, Consolata Siniscalco, Costantino Sirca, Matteo Sottocornola, Luciano Spaccino, Francesco Sposetti, Giampiero Tirone, Michele Tomassucci, Piero Toscano, Andrea Ventura, Andrea Virdiano, Alessandro Zaldei, Roberto Zampedri, Pierpaolo Zara, Terenzio Zenone, Renato Zompanti, Roberto Zorer.

\section{References}

Alberti G, Delle Vedove G, Zuliani M, Peressotti A, Castaldi S, Zerbi G (2010) Changes in $\mathrm{CO}_{2}$ emissions after crop conversion from continuous maize to alfalfa. Agric Ecosyst Environ 136:139-147

Aubinet M, Vesala T, Papale D (2012) Eddy covariance-a practical guide to measurements and data analysis. Springer Science+Business Media B.V., Netherlands, pp 159-172, ISBN: 978-94-007-2350-4

Beer C, Reichstein M, Tomelleri E, Ciais P, Jung M, Carvalhais N, Rödenbeck C, Arain MA, Baldocchi D, Bonan GB, Bondeau A, Cescatti A, Lasslop G, Lindroth A, Lomas M, Luyssaert S, Margolis H, Oleson KW, Roupsard O, Veenendaal E, Viovy N, Williams C, Woodward FI, Papale D (2010) Terrestrial gross carbon dioxide uptake: global distribution and covariation with climate. Science 329(5993):834-838. doi:10.1126/science.1184984, ISSN: 0036-8075

Ciais P, Reichstein M, Viovy N, Granier A, Ogee J, Allard V, Aubinet M, Buchmann N, Bernhofer C, Carrara A, Chevallier F, De Noblet N, Friend A, Friedlingstein P, Grunwald T, Heinesch B, Keronen P, Knohl A, Krinner G, Loustau D, Manca G, Matteucci G, Miglietta F, Ourcival JM, Papale D, Pilegaard K, Rambal S, Seufert G, Soussana JF, Sanz MJ, Schulze 
ED, Vesala T, Valentini R (2005) Europe-wide reduction in primary productivity caused by the heat and drought in 2003. Nature 437(7058):529-533, ISSN: 0028-0836

Chiti T, Papale D, Smith P, Dalmonech D, Matteucci G, Yeluripati J, Rodeghiero M, Valentini R (2010) Predicting changes in soil organic carbon in mediterranean and alpine forests during the Kyoto Protocol commitment periods using the Century model. Soil Use Manag 26(4):475-484. doi:10.1111/j.1475-2743.2010.00300.x, ISSN: 0266-0032

Delpierre N, Soudani K, François C, Le Maire G, Bernhofer C, Kutsch W, Misson L, Rambal S, Vesala T, Dufrêne E (2012) Quantifying the influence of climate and biological drivers on the inter annual variability of carbon exchanges in European forests through process-based modelling. Agric For Meteorol 154-155(15):99-112

FAO, IIASA, ISRIC, ISS-CAS, JRC (2008) Harmonized world soil database (version 1.0). FAO, Rome, Italy and IIASA, Laxenburg, Austria

Gilmanov TG, Soussana JF, Aires L, Allard V, Ammann C, Balzarolo M, Barcza Z, Bernhofer C, Campbell CL, Cernusca A, Cescatti A, Clifton-Brown KJ, Dirks M, Dore S, Eugster W, Fuhrer J, Gimeno C, Gruenwald T, Haszpra L, Hensen A, Ibrom I, Jacobs AFG, Jones MB, Lanigan G, Laurila T, Lohila A, Manca G, Marcolla B, Nagy Z, Pilegaard K, Pinter K, Pio C, Raschi A, Rogiers N, Sanz MJ, Stefani P, Sutton M, Tuba Z, Valentini R, Williams ML, Wohlfahrt G (2007) Partitioning European grassland net ecosystem $\mathrm{CO}_{2}$ exchange into gross primary productivity and ecosystem respiration using light response function analysis. Agric Ecosyst Environ 121:93-120

Lasslop G, Reichstein M, Papale D, Richardson AD, Arneth A, Barr A, Stoy P, Wohlfahrt G (2010) Separation of net ecosystem exchange into assimilation and respiration using a light response curve approach: critical issues and global evaluation. Glob Change Biol 16:187208. doi:10.1111/j.1365-2486.2009.02041.x, ISSN: 1354-1013

Le Maire G, Delpierre N, Jung M, Ciais P, Reichstein M, Viovy N, Granier A, Ibrom A, Kolari P, Longdoz B, Moors E.J, Pilegaard K, Rambal S, Richardson AD and Vesala T (2010) Detecting the critical periods that underpin inter annual fluctuations in the carbon balance of European forests. J Geophys Res 115:G00H03

Mahecha MD, Reichstein M, Carvalhais N, Lasslop G, Lange H, Seneviratne SI, Vargas R, Ammann C, Arain MA, Cescatti A, Janssens IA, Migliavacca M, Montagnani L, Richardson AD (2010) Global convergence in the temperature sensitivity of respiration at ecosystem level. Science 329:838-840. doi:10.1126/science.1189587

Marcolla B, Cescatti A, Manca G, Zorer R, Cavagna M, Fiora A et al (2011) Climatic controls and ecosystem responses drive the inter-annual variability of the net ecosystem exchange of an alpine meadow. Agric For Meteorol 151(9):1233-1243

Maselli F, Papale D, Puletti N, Chirici G, Corona P (2009) Combining remote sensing and ancillary data to monitor the gross productivity of water-limited forest ecosystems. Remote Sens Environ 113:657-667. doi:10.1016/j.rse.2008.11.008, ISSN: 0034-4257

Migliavacca M, Reichstein M, Richardson AD, Colombo R, Sutton MA, Lasslop G, Tomellieri E, Wohlfahrt G, Carvalhais N, Cescatti A, Mahecha MD, Montagnani L, Papale D, Zaehle S, Arain A, Arneth A, Black TA, Carrara A, Dore S, Gianelle D, Helfter C, Hollinger D, Kutsch W, Lafleur PM, Nouvellon Y, Rebmann C, Humberto R, Rodeghiero M, Roupsard O, Sebastià M, Seufert G, Soussana JF, Van Der Molen MK (2011) Semi empirical modeling of abiotic and biotic factors controlling ecosystem respiration across eddy covariance sites. Glob Change Biol 17:390-409. doi:10.1111/j.1365-2486.2010.02243.x, ISSN: 1354-1013

Moffat AM, Papale D, Reichstein M, Hollinger DY, Richardson AD, Barr AG, Beckstein C, Braswell BH, Churkina G, Desai AR, Falge E, Gove JH, Heimann M, Hui D, Jarvis AJ, Kattge J, Noormets A, Stauch VJ (2007) Comprehensive comparison of gap-filling techniques for eddy covariance net carbon fluxes. Agric For Meteorol 147:209-232. doi:10.1016/ j.agrformet.2007.08.011, ISSN: 0168-1923

Montagnani LG, Manca E, Canepa E, Georgieva M, Acosta C, Feigenwinter D, Janous G, Kerschbaumer A, Lindroth L, Minach S, Minerbi M, Mölder M, Pavelka G, Seufert M, Zeri W Ziegler (2009) A new mass conservation approach to the study of $\mathrm{CO}_{2}$ advection in an alpine forest. J Geophys Res-Atmos 114:D07306. doi:10.1029/2008JD010650 
Niu S, Luo Y, Fei S, Montagnani L, Bohrer G, Janssens IA, Gielen B, Rambal S, Moors E, Matteucci G (2011) Seasonal hysteresis of net ecosystem exchange in response to temperature change: patterns and causes. Glob Change Biol 17:3102-3114. doi:10.1111/j.1365-2486.2011.02459.x

PGAF (2009) Piano di gestione ed assestamento forestale, Piano dei Pascoli e relativa Relazione di Incidenza ai sensi del D.P.R. 357/97 delle proprietà silvo-pastorali dell'Università Agraria di Monte Romano (VT)", Committente Consorzio Forestale Tuscia, Convenzione del 07.05.2007, Approvato dalla Regione Lazio con Determina n. B4110 del 22.09.2009

Papale D, Agarwald DA, Baldocchi D, Cook RB, Fisher JB, Van Ingen C (2012) Database Maintenance, Data Sharing Policy, Collaboration. In: Aubinet M, Vesala T, Papale D (eds) Eddy Covariance-A practical guide to measurement and data analysis. Springer Science+Business Media B.V., Netherlands, ISBN: 978-94-007-2350-4

Papale D, Reichstein M, Aubinet M, Canfora E, Bernhofer C, Longdoz B, Kutsch W, Rambal S, Valentini R, Vesala T, Yakir D (2006) Towards a standardized processing of net ecosystem exchange measured with eddy covariance technique: algorithms and uncertainty estimation. Biogeosciences 3:571-583, ISSN: 1726-4170

Petriccione B, Greco S, Tammaro F (1993) La vegetazione del progettato parco archeologiconaturalistico della Valle di Amplero e della Vallelonga (AQ). Micologia e vegetazione mediterranea VIII:137-160

Reichstein M, Falge E, Baldocchi D, Papale D, Aubinet M, Berbigier P, Bernhofer C, Buchmann N, Gilmanov T, Granier A, Grunwald T, Havrankova K, Ilvesniemi H, Janous D, Knohl A, Laurila T, Lohila A, Loustau D, Matteucci G, Meyers T, Miglietta F, Ourcival JM, Pumpanen J, Rambal S, Rotenberg E, Sanz M, Tenhunen J, Seufert G, Vaccari F, Vesala T, Yakir D, Valentini R (2005) On the separation of net ecosystem exchange into assimilation and ecosystem respiration: review and improved algorithm. Glob Change Biol 11:1424-1439, ISSN: 1354-1013

Reichstein M, Papale D, Valentini R, Aubinet M, BernhoferC, Knohl A, Laurila T, Lindroth A, Moors E, Pilegaard K, Seufert G (2007) Determinants of terrestrial ecosystem carbon balance inferred from European eddy covariance flux sites. Geophys Res lett 34(1), ISSN: 0094-8276

Wohlfahrt G, Anderson-Dunn M, Bahn M, Balzarolo M, Berninger F, Campbell C, Carrara A, Cescatti A, Christensen T, Dore S, Eugster W, Friborg T, Furger M, Gianelle D, Gimeno C, Hargreaves K, Hari P, Haslwanter A, Johansson T, Marcolla B, Milford C, Nagy Z, Nemitz E, Rogiers N, Sanz MJ, Siegwolf RTW, Susiluoto S, Sutton M, Tuba Z, Ugolini F, Valentini R, Zorer R, Cernusca A (2008) Biotic, abiotic and management controls on the net ecosystem $\mathrm{CO}_{2}$ exchange of European mountain grasslands. Ecosystems 11:1338-1351

Tedeschi et al (2006) Soil respiration in a Mediterranean oak forest at different developmental stages after coppicing. Glob Change Biol 12:110-121. doi:10.1111/j.1365-2486.2005.01081.x

Venables WN, Ripley BD (2002) Modern applied statistics with S. Springer, New York, pp 498. ISBN: 978-0-387-95457-8

Valentini R, De Angelis P, Matteucci G, Monaco R, Dore S, Scarascia Mugnozza G (1996) Seasonal net carbon dioxide exchange of a beech forest with the atmosphere. Glob Change Biol 2:199-207

Yamashita T, Yamashita K, Kamimura R (2007) A stepwise AIC method for variable selection in linear regression. Commun Stat-Theory and Methods 36:2395-2403

Jung M, Reichstein M, Ciais P, Seneviratne SI, Sheffield J, Goulden ML, Gordon Bonan G, Cescatti A, Chen J, De Jeu R, Dolman AJ, Eugster W, Gerten D, Gianelle D, Gobron N, Heinke J, Kimball J, Law BE, Montagnani L, Mu Q, Mueller B, Oleson K, Papale D, Richardson A, Roupsard O, Running S, Tomellieri E, Viovy N, Weber U, Williams C, Wood E, Zaehle S, Zhang K (2010) Recent decline in the global land evapotranspiration trend due to limited moisture supply. Nature 467:951-954. doi:10.1038/nature09396, ISSN: 0028-0836

Wang T, Brender P, Ciais P, Piao S, Mahecha M, Chevallier F, Reichstein M, Ottlé C, Maignan F, Arain A, Bohrer G, Cescatti A, Kiely G, Law BE, Lutz M, Montagnani L, Moors E, Osborne B, Panferov O, Papale D, Vaccari FP (2012) State-dependent errors in a land surface model 
across biomes inferred from eddy covariance observations on multiple time scales. Ecol Model 246:11-25. doi:http://dx.doi.org/10.1016/j.ecolmodel.2012.07.017, ISSN: 0304-3800

Williams CA, Reichstein M, Buchmann N, Baldocchi D, Beer C, Schwalm C, Wohlfahrt, Hasler N, Bernhofer C, Foken T, Papale D, Schymanski S, Schaefer K. (2012). Climate and vegetation controls on the surface water balance: Synthesis of evapotranspiration measured across a global network of flux towers. Water Resour Res 48(6). doi: 10.1029/2011WR011586, ISSN: 0043-1397

Schulze ED, Wirth C, Heimann M (2000) Managing forests after Kyoto. Science 289:2058-2059 


\section{焦 Springer}

http://www.springer.com/978-3-642-32423-9

The Greenhouse Gas Balance of Italy

An Insight on Managed and Natural Terrestrial Ecosystems

Valentini, R.; Miglietta, F. (Eds.)

2015, VIII, 211 p. 57 illus., 30 illus. in color., Hardcover

ISBN: $978-3-642-32423-9$ 